\title{
APPLICATION OF EVIDENCE-COLLECTION TECHNIQUES IN EXAMINING THE BASIC AUDIT OBJECTIVES IN INSURANCE COMPANIES
}

\author{
Biljana Jovkovic* \\ Faculty of Economics, University of Kragujevac, Kragujevac, Serbia
}

\begin{abstract}
The independent auditor expresses his or her opinion on financial reports, whose primary role is to reduce the asymmetry of information between insurance companies' management and the existing and potential investors. Through reducing the information risk of the presented financial reports, audit provides the safer making of investment decisions of the users of these reports. In order for this basic function of audit to realize, it is necessary that auditors should collect sufficient pieces of evidence by applying adequate and relevant examination techniques. The goal of this paper is to point at the specific position of audit when an insurance company is a client, and in this regard, at a need for the differentiation of the priorities of individual audit objectives as well as the necessity of the customization of the implemented evidencecollection techniques implemented in an audit engagement with an insurance company simultaneously respectfully referring to the prescribed ordinary procedures imposed by the professional regulation. In the paper, an attempt has been made to comprehensively analyze the effectiveness of individual evidencecollection techniques for the purpose of proving the achievement of each individual objective of the audit as well as their different applicability in the examination of certain balance-sheet positions in financial reports of insurance companies.
\end{abstract}

Keywords: evidence-collection techniques, audit objectives, financial reports of insurance companies

JEL Classification: G22, M42

\section{INTRODUCTION}

An audit opinion on financial statements based on the mere observation of the figures presented and items without evidence would resemble guessing, which would have consequences for the people who

\footnotetext{
* Correspondence to: B. Jovkovic, Faculty of Economics, University of Kragujevac; D. Pucara 3, 34000 Kragujevac, Serbia; e-mail: bjovkovic@kg.ac.rs
}

would make their decision based on such an issued statement. The importance of obtaining pieces of evidence is in that they inspire confidence in the work performed by the auditor. The basic phases of the audit process are: defining the conditions of an engagement, planning, risk assessment and internal controls operation, the performance of substantive examination procedures, and the submission of audit reports. The terms of an audit engagement are clearly defined in an engagement letter inclusive of the audit objectives and 
the auditor's and the client's responsibilities. The audit process continues with planning for a more efficient and effective performance. The audit plan and the program containing the nature, volume, and time of audit procedures are documented. Depending on the quality of the internal control system, the volume of tests and substantive testing to be carried out in the process of collecting evidence is determined (Jovković, 2011, 94). In the last phase, the auditor expresses an opinion on the financial statements based on the evidence obtained. The diversity of evidence influences the credibility of the audit report. Evidence must be sufficient, representative and reliable, which is the case when they are collected by applying the appropriate evidence collection techniques that are in accordance with the audit objective whose accomplishment is being tested.

The adequacy of the application of certain audit techniques in the process of examining the achievement of the basic audit objectives for individual balance sheet items in the financial statements of insurance companies is exactly the subject of the research presented in the paper is. The auditor is particularly interested in making sure that insurance companies consistently apply appropriate accounting policies. The following specific positions require special attention to be paid by the auditor: provisions for damage, unearned premiums, the mathematical reserves of life insurance, provisions for risk etc. Due to the high degree of inherent risks characteristic for carrying out this business, there is a risk of the overlooking of some errors. For this reason, the auditor is required to plan his or her audit in insurance with an attitude of special professional skepticism, adapting the procedures of collecting audit evidence for all balance sheet items characteristic for insurance.

The aim is to identify priority audit objectives in investigating certain balance sheet items in financial statements when an insurance company is the audit client, and, in compliance with the determined objectives emphasized in the audit examination, to recommend appropriate and effective techniques for collecting evidence. Based on the analysis of the audit examination objectives and the applied techniques, it is important that the key issues in the implementation of individual and commonly used evidence collection techniques that will enable the identification of the necessary modifications in their implementation should be identified.

The basic hypothesis of the paper which we start from is that the use of certain methods for collecting evidence depends on the individual audit objectives that have a different significance for certain balance sheet items when an insurance company is the client. Insurance companies are major financial institutions and the absence of proving audit examining objectives due to the application of inadequate assessment techniques would produce the uncertainty of the accuracy of their financial statements. In accordance with the defined basic research hypothesis, we will analyze whether the application of the acknowledged evidence-collection techniques in the audit process is more frequent in certain audit objectives if an insurance company is the client.

Respecting the aim and the subject of the research, the adequate methods defined with the research topic are applied in the paper. In order to understand the specifics of the audit process in insurance companies, a comparative analysis of the applied methods and techniques used in auditing insurance companies and other companies as well is applied. The methods of deduction, analysis, synthesis, and particularly the induction procedures are applied, starting from the basic individual assumptions with the purpose of making general conclusions. The paper is supported by a graphical view of the structure of the audit reports according to the opinions expressed in the insurance sector for 2012 and 2011.

Bearing in mind the subject and the aim of the research, as well as the defined hypothesis, the paper firstly analyzes the regulation of the audit profession in the Republic of Serbia. After presenting the key regulatory requirements, attention will be focused on the basic audit objectives and the basic management assertions, whose achievement is examined in the audit engagement. The defining of the audit examination objectives will allow the consideration of the effectiveness of the applied evidence-collection techniques that either confirm or deny the accuracy of the management assertions. The entire analysis will be completed by presenting the structure of the audit reports according to the expressed opinions in the insurance sector in the last two business years, which 
will enable the assessment of the quality of financial reporting in this area and opportunities for improving the audit profession in the future.

\section{AUDIT REGULATIONS IN SERBIA}

The auditing profession in the Republic of Serbia is regulated by the Law on Audit, which was adopted in July 2013. Before its coming into force, this field had also been included along with accounting into the single unit that had been regulated by the Law on Accounting and Auditing. (the Law on Accounting and Auditing, "The Official Gazette of RS", no. 46/2006) Once the new law had come into force, the two fields were separated into the two individual laws. According to the current Law, audit is

"an audit which is obligatory for the regular annual financial statements of large and medium-sized legal entities classified in accordance with the law regulating accounting, of public companies regulated in accordance with the law which regulates the capital market regardless of their size as well as of all legal entities i.e. entrepreneurs whose business turnover in the preceding business year exceeded EUR 4,400,000 in the dinar equivalent. Statutory audit is performed in compliance with this law, the other laws that regulate the mandatory audit of financial statements for individual legal entities, the ISA, and the "Professional Codes of Ethics for Auditors" (Law on Audit, Article 21, Paragraph 1).

Auditing firms are themselves the beneficiaries of insurance with insurance companies. According to the provisions of the Law, "an auditing firm is required to insure against liability for damage done to a legal entity while performing audit activities i.e. to the third party in the case of the breach of the audit contract i.e. the violation of the audit rules" (Law on Audit, Article 18).

\section{THE MAIN OBJECTIVES OF FINANCIAL STATEMENT AUDIT}

The overall objective of the financial statement audit of insurance companies, enterprises, and other clients is to express an opinion on whether such financial statements are, in all materially important aspects, properly presented and prepared according to the defined financial reporting framework (Law on Audit, Article 30, Paragraph 3). To express an opinion on the accuracy of the financial statements of an insurance company, it is necessary that the auditor should be convinced of the accuracy of all the balance sheet items in the financial statements and the disclosure of other relevant information by the management. Accordingly, the realization of the main audit objective and the fulfillment of its primary mission are achieved by decomposing the overall audit objective on a set of objectives, whose successful implementation creates conditions for expressing a competent opinion. The management of an insurance company is primarily responsible for the recording, processing, summarizing and presenting of financial information. (Jovković, 2010, 152) Therefore, specific audit objectives are related to the explicit and implicit management assertions associated with the presented balance sheet items. An assertion is considered to be a statement of the management given either explicitly or otherwise, which is incorporated in their financial statements and directly relates to the fair presentation of the key balance sheet items in these statements. It is necessary for an audit examination to determine whether these assertions made by the management have been achieved or they have failed to fulfill. The realization of the objectives related to the need to check individual balance sheet items creates conditions for the realization of the main objective - giving an opinion on the accuracy and objectivity of the financial statements.

The derived audit objectives whose achievement is necessary to prove by collecting evidence are as follows (Rittenberg, Schwieger \& Johnstone, 2008, 152):

- Existence or occurrence;

- Wholeness or completeness;

- Rights and obligations;

- Valuation or allocation;

- Accuracy;

- Demarcation, and

- Presentation and Disclosure. 
The first derived objective of the financial statement audit of an insurance company refers to the examining and proving of the management's assertions that the assets, equity and liabilities of the company that are presented do exist, that is to say, that the presented revenues, expenses and gains or losses actually took place in the given accounting period. An assertion needs to be proved for both the balance sheet items that have the material form of existence, such as fixed assets, cash, land, securities etc., and for the balance sheet items that are non-material, such as claims for contractual premiums, claims from coinsurers and reinsurers, liabilities for insurance claims and the like. Different evidence-collection techniques are applied, depending on whether the assets of an insurance company have a material or a non-material form. The auditor will be convinced of the existence of building structures by visiting the premises, whereas for the confirmation of the existence of claims for premiums, it will be necessary to seek the confirmation of the counterparty, which means that the confirmation technique will be applied. The application of this technique first requires access to contracted insurances, then a review of the submitted open-item statements and sending requests for confirmation to the insured in order to gain confidence that the presented claims truly exist. The evidence-collection technique provides assurance that the audit objective has been achieved, rather than some other, such as a proper valuation, for whose examination another appropriate technique is necessary to apply. The above statement may be misrepresented if the amount of realization includes part of a fictitious realization, or if the value of the balance sheet items includes the transactions that have occurred after the termination of the accounting period. When the auditor is analyzing the accuracy of the assertions of the management on the existence or occurrence in the insurance company, as opposed to clients from other sectors, the auditor is mainly concerned with a possibility of the overvaluation of the balance of certain balance sheet items through the inclusion of the balance sheet items that do not exist or the inclusion of the effects of the transactions that did not truly occur (the presentation of fictitious claims for premiums, the presentation of claims from coinsurers - where such rights do not exist etc. are just some of the examples of an overvaluation of balance sheet items). In the Group 24 accounts, an insurance company shall disclose its cash equivalents, cash, immediately bankable securities, and demand deposits. Given the uncertainty of risk emergence, there is a need for insurance organizations to own significant funds in order to be able to meet their potential liabilities to policyholders. The objective of the existence is in the center of the audit of financial resources and the auditor is primarily interested in testing its achievement, while testing other objectives achievement has a secondary character, and they do not pose a particular problem to the auditor in the testing process. One of the basic procedures of the assurance of the existence of the above funds is the attendance of the auditor in inventorying cash. Due to the independent auditor's attendance in the inventorying and examining of the record of the Committee for inventorying cash, cash equivalents, and securities, the evidence on the existence of the above funds as well as possible discrepancies between the inventory and the book balance are acquired.

Completeness is the audit objective which refers to the need that financial statements show all the economic transactions and the amounts that occurred in the insurance company in the period covered by the financial report. Completeness means showing all the revenues and expenditures, changes in equity, liabilities, and assets that occurred during the reporting period (Eilifsen, Messier, Glover \& Prawitt, 2014, 129). Therefore, the assertion of the management is that balance sheets include all liabilities, assets, equity, revenues, expenses, gains and losses. By performing appropriate evidence-collection methods, it is necessary to prove whether all the transactions and accounts that should be included in financial statements are actually included and that there are no undisclosed assets, liabilities, or omitted transactions. When performing an audit in an insurance company, the necessity of acquiring the belief that the income statement of the insurance company includes all the transactions of the sales of the insurance services in the accounting period and that there are no omitted transactions in that respect is emphasized. The checking of the completeness of assertion is what the testing of the existence of the possible undervaluation of certain balance sheet items, i.e. determining whether there is 
omission of some balance sheet items and effects of certain transactions that should be included in balance sheet reports (omitting the presentation of liabilities for claims, omitting the presentation of provisions on various grounds that are necessary to carry out etc.) is aimed at. To uncover the omitted transactions or parts of the balance sheet items with auditing procedures is much more difficult than testing the assertion of the existence, as the starting point of examination is what needs to be entered, not what has been entered. The transaction that is most frequently left out has no material trace in the records of an insurance company and the documentation indicative of the occurrence of the transaction is frequently absent. When an omission of transactions is observed, the problem of the accuracy of the amounts that should have been included implies the inaccuracy of the assertions of the management on accuracy and evaluation. This objective is of special importance in auditing clients in insurance because an incomplete presentation of the sale of the insurance services entails two consequences: the undervaluation of revenues at the time of sale and the occurrence of liabilities for claims when the risk is realized. The effect of negative consequences is twofold: the absence of entering revenues and the emergence of expenditures where there are no accrued revenues. The document inspection technique is used for proving the accomplishment of the objective of the completeness in audit in the following accounting period, usually for transactions of payment and collections of cash. By reviewing transactions in the following period, it is possible to detect cash payments arising from the liabilities that were not included at the balance sheet date and should have been reported, or there was a collection of cash based on claims by, for example, the coinsurer, that were not shown on the balance sheet. The reason for moving the examining period to the following period lies in that, in the case of the unfulfilled objective of completeness, there is no material trace in accounting, which confirms that there are real business events that should have been included in the records. Therefore, the transactions of the following period are tested in order to draw conclusions retroactively about the existence of undervaluation.
The derived audit objective concerning the rights and the obligations is related to the need to assure auditors that the property is owned by the particular insurance company i.e. that the obligations are the company's debt obligation in a particular accounting period. An insurance company has presented demand deposits and time deposits at commercial banks in the balance sheet since they keep part of technical provisions in a liquid form; therefore, when it comes to these items, the priority is to assure that the company has the right of the ownership of the assets presented. The auditor is convinced of the ownership of the demand deposits at commercial banks and the existence of any possible restrictions on access and use (given the lien statement) using the basic audit technique of confirmation from the independent third party, in this case - the bank. Based on the confirmation, if the banks have confirmed the presented amounts to the auditor, it can be concluded that the assets exist, they are the property of the insurance company, and are accurately presented. In this way, the assurance of the achievement of many audit objectives can simultaneously be obtained. The right of ownership needs to be proven for the other types of assets as well, such as land with an abstract from the land registry, equipment based on the sales contract etc. In the case of the sale of an insurance service, when the policyholder fails to immediately pay the a corresponding premium, the insurance company has the right to present the corresponding claim as the company property (the Law of Obligations, Article 148, paragraph 1) on the basis of the debtor-creditor relationship arising from such insurance. Based on the record of the resulting, declared and recognized damage of the policyholder based on the realization of the insured risk, the insurance company is obligated to pay for the damages and, therefore, it presents the resulting obligations. The assertions of the management regarding the rights and obligations of the company only concern only the balance sheet items and, by applying appropriate techniques (the confirmation and the document inspection techniques), the auditor is assured of the validity of the assertions.

An assertion of the management with respect to valuation and allocation refers to the presentation of the assets, liabilities, equity, income and expenses in 
the financial statements of a company in appropriate amounts. When it comes to an insurance company, it is extremely important that the elements of financial statements be properly valuated and that there should be no under- or overvaluation of the balance sheet items. A special emphasis in the audit process is put on receivables from business relations included in the balance sheet and it is necessary to prove that they reflect the actual payable amount. The area that the auditor checks with special professional skepticism is the correct calculation of allowance for the impairment of receivables, which directly influences and determines the accuracy of the presented amounts. Reporting liabilities on reserving for the equalization of the company's obligations for the risks taken in a series of accounting periods is often present and is typical of insurance companies, so it is important that the value of the specified liabilities should properly be expressed so as to avoid their under- or overvaluation. Long-term provisions are calculated in insurance companies with the aim of creating a cover for risks taken. The most important objective is to make sure they have properly been valuated i.e. whether they are over- or undervalued. The undervaluation of longterm provisions would result in the presentation of the better financial situation of the company in the observed period, which could cause the company to become illiquid or insolvent in the case of risk events. When long-term provisions are overvalued, the latent provisions are created in the company, i.e. larger calculations on the provisions for expenses in the current period will present a smaller periodic result than it should be according to the actual state of the matters. If provisions in the following period are properly calculated, the surplus of the previously calculated provisions will be eliminated in favor of the revenue, which would mean moving part of the gain from one accounting period to the other and its misrepresentation in a series of accounting periods. In the auditing process, it is necessary to be assured of the regularity of the valuation and disclosure of long-term provisions for risk equalization for another, however no less significant, reason. Specifically, these provisions are part of the technical provisions of an insurance company in addition to unearned premiums and claims provisions. Technical provisions are established to protect the interests of policyholders and stand for the reserves deposited in certain specified types of investments in order for insurance companies to be able to respond to claims for compensation arising from the risks assumed by the insurance contract at any point in time in their business doing. The basic technique used in testing the valuation of provisions is the calculation control technique, with the application of the actuarial method of provision calculation. In the implementation of this technique, unlike other audit engagements, the auditor needs to have the knowledge of the actuarial profession in order for such an assessment to be valid.

Accuracy is an assertion relating to the mathematical accuracy of transactions recorded in financial statements as well as a proper addition and the recording of these transactions in the synthetic records. For example, it is necessary to be sure that the mathematical calculation of the distribution of gross premiums to the part related to the technical premium and expense loading and then the distribution of the corresponding amounts of the premium to the periods of the policy duration are accurate. Similarly, to examine the accuracy of the calculation of liabilities for claims reported by policyholders, which are reported and liquidated or reported however not liquidated during the accounting period. The auditor directs his or her special attention to the examination of the regularity of the mathematical calculation of unearned premiums, mathematical reserves and provisions for risk equalization. An examination is carried out over whether the calculation is properly executed and whether the provision is covered in the prescribed forms of the records. The calculation control technique is the most commonly applied one. During the examination of such a balance sheet, when for example an audit client has funds in a foreign currency account, it is then necessary to make sure that his or her foreign funds are properly converted into the dinar equivalent and that the determined exchange losses are properly covered (International Financial Reporting Standards, 112). The examination begins by inspecting the structure of the funds on such a foreign currency account, the assessment of assets in the dinar equivalent against the middle exchange rate of the National Bank of Serbia at the balance sheet date, in 
accordance with the provisions of the law (the Law on Accounting, Article 6, Paragraph 5).

Demarcation as an audit objective implies that all the transactions that occurred near the date of the periodic results calculation are recorded and displayed in the period which they actually refer to in compliance with the requirement of the basic accounting principles of the causality of the confrontation of corresponding expenditures with corresponding revenues. This problem is particularly present in insurance companies since there is a discrepancy between the time of the conclusion of the insurance contract (the insurance time duration) and the result calculation period. In this regard, the key problem is to determine the accuracy of the demarcation of the collected premiums on the earned premium and the unearned premium referring to the future accounting periods. The misallocation of premiums between the earned and the unearned parts has resulted in incompletely reported revenue in different accounting periods, resulting in the misstatements of the achieved periodic results and the misstatements of the sum of the balance sheet if the unearned premiums, as the passive positions, are under- or overvalued. By means of the document inspection technique, an analysis of the calculation of unearned premiums for every type of insurance that the company has in its portfolio should necessarily be carried out, the analytical records the demarcation of premiums to the earned and the unearned ones should necessarily be reviewed and the accounting entries based on the performed calculation should be implemented. In the sample document analysis, the auditor will examine the data on the basis of which his or her calculation has been made, as follows: the premium amount, the date of commencement and the expiration of insurance coverage, the number of days of insurance, the number of days of insurance after the periodic calculation, the amount of insurance coverage - the risk at the beginning of the insurance period, the amount of the insurance coverage - the risk at the end of the insurance period, and the like.

The objective of presentation and disclosure refers to the assurance of the fact that all the components of financial statements are properly classified and described and that necessary disclosures are made in the notes in addition to financial statements. If there are certain restrictions over the property or access to certain forms of the property, if there is information about the obligations that may be relevant to users of financial statements, then those facts must be disclosed. By applying the techniques of the examination of the management, the auditor learns if he or she has achieved the presentation and required disclosures objective, and makes a decision on meeting this objective by financial reporting on the insurance company.

Not only does the quality of the financial statements of an insurance company depend on the preparation of the statement at the end of the accounting period, but it also depends on the inclusion of every business transaction during the accounting period. More precisely, every business transaction has its own documentation, recording and reporting aspects. (Pjanić, Stojanović \& Jakšić, 1994, 1277). Only those transactions which are confirmed by a document as a written identification of its emergence can be considered as relevant transactions (Pjanic et al, 1994, 1277). The correct documents, as the basis of records, provide a confirmation to the overall quality of the accounting system of the society and are the thread that runs through the recording aspect to the very reporting, determining the accuracy and objectivity of the report. The reporting aspect of transactions is a need for data systematization in business books and their presentation in the prescribed forms. According to the Law on Accounting (2013, Article 2, Paragraph 1, Item 7 ), insurance companies are required to prepare an annual conclusion consisting of: the balance sheet, the income statement, the statement of the achieved results, the cash flow statement, the statement of changes in equity, and notes in addition to the financial statements. These statements are subject to statutory audit and the auditor gives an opinion on their accuracy and objectivity in the auditor's report, thus achieving the main objective of an audit.

\section{EVIDENCE-COLLECTION TECHNIQUES}

An audit examination is a carefully planned activity aimed at determining activities to be conducted during an audit engagement. The most important 
parameter the auditor should express while planning activities is the risk that the auditor is willing to accept in his or her engagement. It is used for defining adequate evidence-collection techniques and the implementation of the examining procedures that will lead to the achievement of the basic audit objectives.

The techniques used in obtaining evidence are: (Whittington \& Pany, 2014, 143)

- Inspection;

- Observation;

- Inquiry and confirmation;

- Calculation control, and

- Analytical procedures.

The inspection (review) of documents and reports consists of examining records and documents, either internal or external, in paper or in an electronic form. The review of documents enables the auditor to gain an accurate knowledge of the conditions in the agreements concluded by the insurance company or the provisions of the insurance policies issued. Some documents represent direct audit evidence on the existence of funds. For example, a piece of evidence is a financial instrument, such as a stock or a bond, and by reviewing it, one can acquire a belief of the existence of these funds. However, the review of these documents may not necessarily provide audit evidence about the value of assets whose existence is proven. During an inspection, the auditor can assess the accuracy of the documents, or may reveal the existence of changed or suspicious positions in the document. Confirmation and searching are two important examination processes in auditing, associated with the inspection of documents. Confirmation involves the selection of positions in the financial statement and the review of documents that form the basis for the entry of the transactions related to the balance sheet position in order to determine the validity and accuracy of the entries. For example, when testing the sales of insurance services, the auditor can choose transactions from the sales journal and confirm the transaction by reviewing the insurance policy. Confirmation is extensively used for the detection of overvaluation in financial statements. So, this is an important procedure in obtaining evidence related to the assertion of existence or occurrence. In searching, the auditor selects documents created when the transaction occurred and analyzes whether the document has properly been entered in the records and contained in the financial statement position. In searching, the direction of testing is opposite to the one used in confirmation; it starts from documents towards the financial statement, by reconstructing the original data flow through the accounting system. For example, when testing the completeness of the sale of insurance, the auditor can select a sample of insurance policies and monitor the transaction throughout the entries in the sales journal and the general ledger. Since this procedure provides assurance that the data from the original documents are included in the final account balance, it is especially beneficial for the detection of a restraint in financial statements. This is an important procedure in gaining evidence related to the assertion of completeness. Review or inspection may be used for the acquisition of evidence on the physically present assets in insurance companies. The review of visible, tangible assets provides the auditor with direct personal knowledge of their existence and physical condition. Although the review of visible assets, such as observing a company's equipment, its business premises, the means of transport etc. provides the strong evidence of the assertion on existence, this procedure does not provide evidence on the rights of the company over the assets.

Observation is a technique that consists in monitoring the process or procedures performed by another person, e.g. inventorying supplies. Observation relates to the observing of the existing means or procedures performed by another person. An activity can routinely be treated in a particular type of transaction, such as when receiving cash to see if the employees perform their duties in accordance with the policies and procedures of the company. Observation is particularly important in acquiring the understanding of the internal control. Through these observations, the auditor acquires direct personal knowledge of the audit objectives. The auditor should be careful when assessing the reliability of the audit evidence obtained through observation because it is limited by the time it is performed in. For example, when the auditor performs an internal control observation, pieces of evidence are limited in that they are indicative of the 
operation at the time of the particular observation, i.e. the client's personnel can be at their best behavior complying with the internal control procedures when the audit team are present and observe the execution of certain business transactions.

Inquiry is a technique for obtaining information from employees in a legal entity or from external experts. Inquiry means seeking information from the wellinformed client's personnel, either in the financial or the non-financial sector. It is often carried out additionally, along with other audit procedures. It is implemented through obtaining evidence about the functioning of the internal control system. In auditing accounting estimates, it is necessary to obtain an opinion of the certified actuary in order to gain assurance that the estimates of the provisions are properly being conducted. Inquiry can be formal (written) and informal (verbal). Written statements have a higher value for the ease of proof and reference. Answers obtained through inquiry can provide the auditor with the information which he or she did not previously have or the one confirming other pieces of evidence. For example, an effective inquiry may direct the auditor towards marking an unexpected risk of material errors, or inquiring can confirm the auditor's understanding of the client's internal control. Answers may provide information significantly different from other evidence the auditor has obtained. For example, an inquiry of employees in the accounting department can provide the auditor with information on the existence of the ignoring of internal control by managers. In this case, such an inquiry provides guidance for auditors to adjust or perform additional audit procedures. The reliability of the audit evidence obtained through inquiring is under the influence of the skills, knowledge and experience of the auditor's in his or her performing an inquiry given that the auditor is the one to analyze and evaluate responses during the execution of an inquiry and he or she improves subsequent questions according to the given responses.

Confirmation is a technique of finding the confirmation of the information contained in the financial statements addressing third parties independent of the company which is the client in an audit. It is the process of acquiring representative information on the current conditions directly from the third party. This leads to information about the existence, over- or undervaluation of the assets of an insurance company. A request for the confirmation of the balances arising from the contractual relationship between an insurance company and its insured, financial institutions and other third parties is made in writing and submitted to the third parties selected by the auditor. When the application of a technique in an insurance company is concerned, it is important that the auditor is entirely in control of the selection of the items that will be subject to a confirmation to the third party, making requests for a confirmation and the process of sending a request to third parties. The third party sends a response to the confirmation directly to the auditor's address. In practice, there are two types of confirmation applied: positive and negative confirmation (International Standards on Auditing, 215). A positive confirmation requires from the third party to provide a response to the request regardless of whether the requested information is true or not, i.e. whether there is a confirmation of the requested amount or a discrepancy in the stated amount. A negative confirmation requires a response on the third party's part only if there is a discrepancy in the stated amount. The application of a positive confirmation provides greater security given the fact that, in any case, third parties respond to the request made by the external auditor. Confirmation is used in auditing since evidence is objective and is derived from an independent source.

Calculation control or recalculation refers to the verification of the mathematical accuracy of documents or records. Generally speaking, auditors use audit software to perform recalculations for analytical accounts receivable and for matching with the amounts in the general ledger. This is often an important starting procedure. For example, the auditor first wants to make sure that the details of the analysis of accounts receivable for premiums match with the general ledger balance before he or she has decided to send a confirmation.

Analytical procedures include an analysis of significant indicators and trends, including an investigation of the fluctuations and relationships inconsistent with other relevant information or those deviating from the expected amounts. A comparison of the calculated values with the values achieved 
in the previous period, the planned values, or the actual values of other insurance companies can be performed. Analytical procedures refer to an assessment of the financial information stated in the statements of the company on the basis of studying the relationship between both financial and nonfinancial data. Analytical procedures may be used in the stage of audit planning, in the stage of collecting substantial evidence as well as in the stage of a general review at the end of the audit. Analytical procedures are generally used for developing expectations for the amounts in financial statements and for the purpose of assessing the acceptability of financial statements in this regard. These procedures are based on the assumption that the dependence between the observed data will continue in the future unless some special circumstances lead to a change in the trends. Unusual transactions or business events, changes in the accounting policy, changes in operations, errors and illegal acts and the occurrence of random events can serve as examples of the occurrence of the particular circumstances leading to the discontinuity of the observed trends. Analytical procedures may be in the form of an analytical review or analysis. An analytical review refers to a need to examine individual documents that provide us with pieces of evidence, for example on the placement of insurance organizations, on the security of the placement and is a substantive examination of the balance sheet items. An analytical review of the contents of the revenues from insurance premiums determines the existence of the concentration risk in the insurance portfolio, the concentration of a specific geographical area, or the insured. An analysis refers to the calculation of the indicators and trends based on the data derived from statements of insurance companies and, comparing results with planned results, the results of the previous period, or an industry trend, appropriate conclusions are derived.

Due to the achieved level of the development of information technologies and software, it is possible to apply many of the evidence-collection techniques in the audit process using software customized for audit purposes. Computer-assisted audit tools and techniques (CAATT) use audit software in order to perform many of the evidence-collection techniques (Boynton \& Johnson, 2006, 246). The evidence may be of varying degrees of reliability, depending on the availability of evidence and the method of its creation, recording, and the correspondence of the documents as shown in the Figure 1.

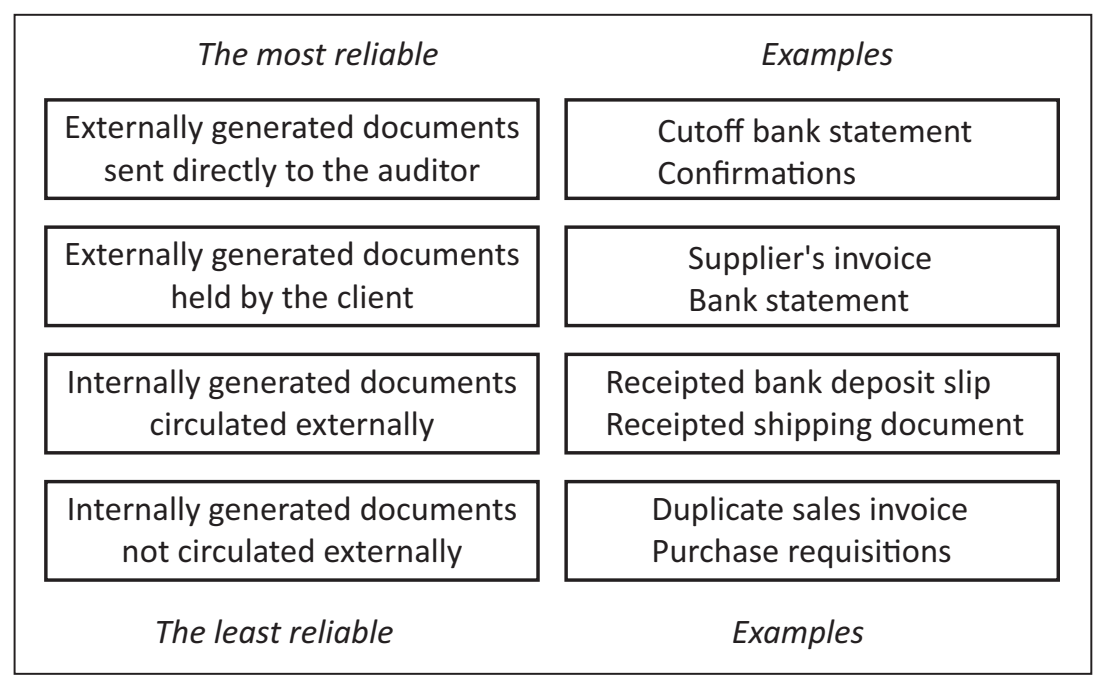

Figure 1 The impact of the movement of documents on the reliability of evidence 
The most reliable source of evidence for the auditor in the examination of the financial statements of an insurance company provides the use of the confirmation technique given that insurance companies hold a significant amount of assets in the form of cash for the purpose of settling claims. The least reliable pieces of evidence are documents on the claim assessment, as they are created internally in an insurance company and are the basis for entering the most important expenditures - expenditures on compensation, which are the largest according to the share in the total operating expenses.

\section{THE AUDIT OPINION ON INSURANCE COMPANIES IN SERBIA FOR THE YEARS 2012 AND 2011}

The auditor shall submit a report setting out the auditor's opinion on the accuracy and objectivity of the financial statements. The auditor's opinion may be: an unqualified opinion, a qualified opinion, a disclaimer of an opinion, and an adverse opinion (Hooks, 2011, 596).

The unqualified audit opinion is the most desirable form of opinion for an audit client, the users of financial statements and for the auditor him- or herself. It is expressed when, based on an analysis of the collected evidence, the auditor believes that the financial statements in all material respects fairly present the financial position of the company, its financial performance, changes in equity, and the cash flows for the audited year, in accordance with the international accounting standards and regulations. When the auditor discovers irregularities bearing no great importance for him or her to express a qualified opinion, but being not unimportant to be ignored, the auditor expresses an unqualified opinion drawing attention to some issues or minor oversights noted during the audit. A qualified opinion is given for financial statements properly presented in compliance with the accounting standards and legal requirements, except for some irregularities that are material in nature and essential for decision-makers - users of financial statements and of the auditor's report, but have no fundamental significance that would lead the auditor to express an adverse opinion. When the auditor has more reasons for a qualified opinion, it is then necessary that the cumulative effect of the overall findings which are the basis for a qualified opinion should be assessed (Soltani, 2007, 349). If the cumulative effect of the basis of discrepancies is such that it affects the accuracy of financial statements, then the discrepancies can be characterized as fundamental oversights suggesting that the auditor should formulate an adverse opinion.

When the nature of the perceived problem is such that it completely challenges the usefulness of the financial statements for users, the discrepancies are considered as fundamental and such financial statements are deemed to be unreliable in the auditor's opinion. In the case of the fundamental deficiencies, the auditor's qualified opinion would not be a sufficient warning to the users of the audit reports on and the financial statements of insurance companies with respect to the false information about the financial and earning position of the company. If, due to the circumstances of performing audit procedures, there is an uncertainty about the accuracy of certain balance sheet items which the auditor has no evidence on and such an uncertainty has a fundamental impact on the financial statements as a whole, the statements are considered as unreliable and the auditor disclaims an opinion in the audit report due to the lack of evidence. A disclaimer of opinion is more related to the conditions of audit performance than to the character of the financial statements.

When an insurance company is the audit client, the independent auditor's report is specific compared to the one on other companies because the independent auditor's report must be structured in compliance with the requirements of the Resolution on the contents of the audit report on an insurance company's financial statements, adopted by the National Bank of Serbia. According to the Resolution ("The Official Gazette of RS", no. 54/ 2005) the audit report contains the auditor's opinion and his or her report as well as analyses and appendixes. An analysis with the audit report includes: general information on the company, an internal control system analysis, a bookkeeping analysis, a balance sheet analysis, the income statement, the cash flow statement, the statement of 
changes in equity, notes to the financial statements, the indicators of company operations, an analysis of the human resources, the organizational and technical capacity of the company, an internal audit functioning analysis, and an external control findings analysis. The reasons for prescribing the stated analyticity and the presentation of the analyses lie in the importance of insurance, from a social aspect, and a need for maintaining the necessary financial discipline. A lack of trust in the financial reporting of the companies, a lack of the necessary credibility of the information contained in financial statements would have a domino effect on the security breach that insurance should provide both in the financial and the real sectors of the economy. The auditors expressed their opinions in their reports for the insurance sector in the Republic of Serbia, globally observed, for the business years 2012 and 2011, as shown in the Table 1.

Table 1 The auditor's opinions in the audit report for the insurance sector in 2011 and 2012 and the review of the audit companies engaged by the insurance companies

\begin{tabular}{|c|c|c|c|c|c|}
\hline NO. & NAME OF COMPANY & $\begin{array}{l}\text { AUDITOR'S OPINION } \\
\text { IN REPORT } 2011\end{array}$ & $\begin{array}{l}\text { NAME OF AUDIT } \\
\text { COMPANY }\end{array}$ & $\begin{array}{l}\text { AUDITOR'S OPINION } \\
\text { IN REPORT } 2012\end{array}$ & $\begin{array}{l}\text { NAME OF AUDIT } \\
\text { COMPANY }\end{array}$ \\
\hline 1 & METLIFE & Unqualified & DELLOITE & Unqualified & DELLOITE \\
\hline 2 & AMS & Unqualified & VINČIĆ & Unqualified & VINČIĆ \\
\hline 3 & AXA NEŽIVOTNO & Unqualified & PWC & Unqualified & PWC \\
\hline 4 & BASLER NEŽIVOTNO & Unqualified & PWC & Unqualified & PWC \\
\hline 5 & BASLER ŽIVOTNO & Unqualified & PWC & Unqualified & PWC \\
\hline 6 & CREDIT AGRICOLE LIFE (AXA) & Unqualified & PWC & Unqualified & PWC \\
\hline 7 & DDOR RE & Unqualified & KPMG & Unqualified & KPMG \\
\hline 8 & DELTA GENERALI & Unqualified & PWC & Unqualified & ERNST \& YOUNG \\
\hline 9 & DELTA GENERALI RE & Unqualified & PWC & Unqualified & ERNST \& YOUNG \\
\hline 10 & DUNAV OSIGURANJE & Unqualified & KPMG & Sa rezervom & KPMG \\
\hline 11 & DUNAV RE & Unqualified & KPMG & Unqualified & KPMG \\
\hline 12 & ENERGO PROJEKT GARANT & Unqualified & MOORE STEPHENS & Unqualified & MOORE STEPHENS \\
\hline 13 & GLOBOS & Unqualified & MOORE STEPHENS & Unqualified & MOORE STEPHENS \\
\hline 14 & GRAWE & Unqualified & KPMG & Unqualified & KPMG \\
\hline 15 & MERKUR & Unqualified & KPMG & Unqualified & KPMG \\
\hline 16 & SAVA ŽIVOTNO & Unqualified & KPMG & Unqualified & KPMG \\
\hline 17 & UNIKA NEŽIVOTNO & Unqualified & KPMG & Unqualified & KPMG \\
\hline 18 & UNIKA ŽIVOTNO & Unqualified & KPMG & Unqualified & KPMG \\
\hline 19 & WIENER & Unqualified & KPMG & Unqualified & KPMG \\
\hline 20 & WIENER RE & Unqualified & KPMG & Unqualified & KPMG \\
\hline 21 & DDOR NOVI SAD & $\begin{array}{l}\text { Unqualified opinion } \\
\text { with drawind attention }\end{array}$ & ERNST \& YOUNG & Unqualified & ERNST \& YOUNG \\
\hline 22 & MILENIJUM & $\begin{array}{l}\text { Unqualified opinion } \\
\text { with drawind attention }\end{array}$ & $\begin{array}{l}\text { PRIVREDNI } \\
\text { SAVETNIK }\end{array}$ & $\begin{array}{l}\text { Unqualified opinion } \\
\text { with drawind attention }\end{array}$ & $\begin{array}{l}\text { PRIVREDNI } \\
\text { SAVETNIK }\end{array}$ \\
\hline 23 & SOCIETE GENERALI & $\begin{array}{l}\text { Unqualified opinion } \\
\text { with drawind attention }\end{array}$ & DELLOITE & Unqualified & ERNST \& YOUNG \\
\hline
\end{tabular}




\begin{tabular}{|c|c|c|c|c|c|}
\hline NO. & NAME OF COMPANY & $\begin{array}{l}\text { AUDITOR'S OPINION } \\
\text { IN REPORT } 2011\end{array}$ & $\begin{array}{l}\text { NAME OF AUDIT } \\
\text { COMPANY }\end{array}$ & $\begin{array}{l}\text { AUDITOR'S OPINION } \\
\text { IN REPORT } 2012\end{array}$ & $\begin{array}{l}\text { NAME OF AUDIT } \\
\text { COMPANY }\end{array}$ \\
\hline 24 & TAKOVO & $\begin{array}{l}\text { Unqualified opinion } \\
\text { with drawind attention }\end{array}$ & VINČIĆ & Sa rezervom & VINČIĆ \\
\hline 25 & SAVA & $\begin{array}{l}\text { Unqualified opinion } \\
\text { with drawind attention }\end{array}$ & KPMG & $\begin{array}{l}\text { Unqualified opinion } \\
\text { with drawind attention }\end{array}$ & KPMG \\
\hline 26 & TRIGLAV KOPAONIK & $\begin{array}{l}\text { Unqualified opinion } \\
\text { with drawind attention }\end{array}$ & KPMG & $\begin{array}{l}\text { Unqualified opinion } \\
\text { with drawind attention }\end{array}$ & ERNST \& YOUNG \\
\hline 27 & AS NEŽIVOTNO & Sa rezervom & VINČIĆ & $\begin{array}{l}\text { Unqualified opinion } \\
\text { with drawind attention }\end{array}$ & VINČIĆ \\
\hline 28 & SOGAZ OSIGURANJE & & & Unqualified & PWC \\
\hline
\end{tabular}

Source: Author, based on the disclosed financial statements for insurance companies individually, http://www.nbs.rs/internet/ cirilica/60/60_1/60_1_1.html, the time of the review: February 2014

Out of the 28 insurance companies in Serbia in 2012, the 22 companies received an unqualified opinion, the four companies received an unqualified opinion with drawing attention, and the two companies received a qualified opinion. Compared to the prior year, there was an increase in the share of unqualified audit opinions by $4 \%$ (from $74.07 \%$ to $78.57 \%$ ), as can be seen in the Figure 2.

\section{CONCLUSION}

The main objective of audit stems from the role of audit to verify financial statements and to authoritatively and

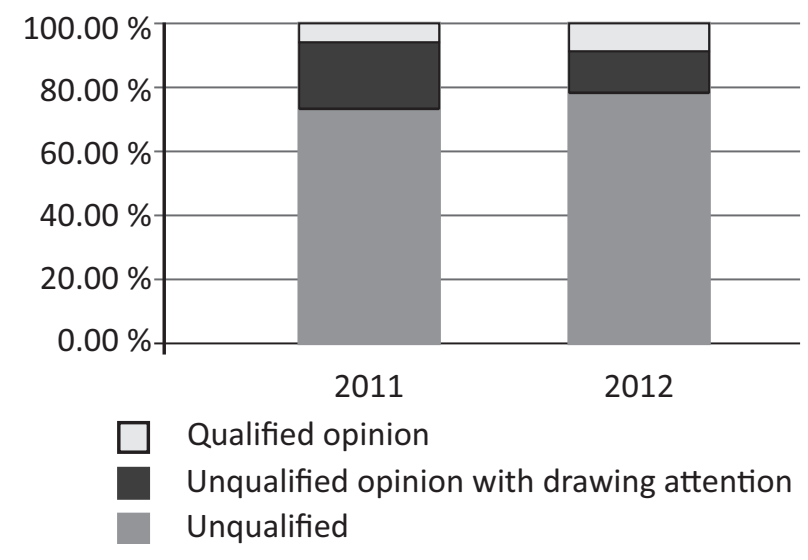

Figure 2 The share of the auditor's opinions for the insurance companies in 2011 and 2012

Source: Author competently communicate an opinion on the accuracy and objectivity of financial statements to interested users. A realistic picture on the financial stability of an insurance company is important to protect the interests of the current and potential clients. An overvaluation of assets, in order to conceal an unauthorized appropriation of a company's assets, would directly endanger the interests of the insured given the fact that the insurance company would encounter difficulties to fulfill its obligations at the time of a risk event and a need for compensation. The role of the insurance industry - to compensate to policyholders and provide security - would be challenged if insurance companies themselves were not able to respond to servicing the incurred obligations to policyholders. Due to the social importance of insurance, there is an emphasized need of the real financial reporting of insurance companies and a need for conducting the audit of their statements with special professional skepticism in order for users of audited financial statements to rely on the information disclosed in them. Otherwise, insurance would not provide security in the community but, on the contrary, would rather be a source of uncertainty that has far-reaching negative effects due to the domino effect in the financial system of a country.

The key hypothesis which the paper started from has been confirmed through the use of appropriate evidence-collection techniques, depending on which individual audit objectives are to be confirmed in the examination of individual balance sheet items in 
the financial statements of insurance companies. The paper also confirms that individual audit objectives do not have the same importance for each balance sheet position; some audit objectives, such as existence and ownership, are emphasized when the auditor is checking active balance sheet positions; on the other hand, audit objectives such as valuation and completeness are emphasized when examining passive balance sheet positions, especially in the examination of claim provisions and long-term provisions.

The main contribution of the paper lies in the analysis of the adequacy of the application of the existing methods and the testing procedures used by auditors in the process of collecting evidence on the financial statements of insurance companies and the critical review of their adequacy to the specifics of the business activities carried out by an insurance company. The analysis provides the defining of the suggestions for the improvement and modification of certain techniques in accordance with the differentiation of the priority of certain audit objectives.

The objective of existence is preferred to the other audit objectives when examining the funds of an insurance company, which requires an improvement of the confirmation technique in terms of its exclusive use in the form of a positive confirmation and its use for examining all deposits that make up the technical provisions of a company. The uncertainty of the risk emergence necessitates keeping large amounts of cash in an insurance company, which increases a possibility of its embezzlement. The audit objective of completeness is considered to be the primary objective for examining the income statement and a company's liabilities in the balance sheet. A more detailed examination of the objective of completeness imposes the necessity of a consistent approach of searching in evidence collection. This evidence-collection method is necessary to adjust when it comes to examining in an insurance company, in terms of its extensive application to an increasing number of the examined units by exclusively using a random sample of the entire population of the same document type.

The main limitation of the paper relates to the partial analysis of the application of the evidence-collection techniques only to the most important and specific balance sheet items in insurance companies without deepening this issue on all the balance sheet items that exist in the society and in companies engaged in other activities so as to avoid the unnecessary extensiveness of the paper. It also shows the application of the most important evidence-collection techniques adjusting in evidence collection in insurance companies, but not all the techniques for all the audit objectives. Since insurance is based on the existence of risk, future research should focus on examining assumed risks and the risk of an insurance company's business activities, with the relevant verification methods used by the auditor in order to, based on the analysis, enable an improvement of the audit evidence collection procedures in auditing financial statements of insurance companies. Improving the audit procedures through the adaptation of the application of the known evidence-collection techniques increases the credibility of financial statements and makes business decision making based on audited information safer.

\section{ACKNOWLEDGEMENT}

This work is a part of the Project number 42013, funded by the Ministry of Education, Science and Technological Development of the Republic of Serbia.

\section{REFERENCES}

Boynton, W., \& Johnson, R. (2006). Modern Auditing Assurance Services and the Integrity of Financial Reporting. New York, USA: Jonh \& Sons.

Cosserat, G., \& Rodda, N. (2009). Modern auditing. London, UK: Wiley \& Sons.

Eilifsen, A., Messier, W., Glover, S., \& Prawitt, D. (2014). Auditing $\mathcal{E}$ Assurance Services. London, UK: McGraw-Hill Education.

Financial statements of insurance companies, (2012 and 2011) available at http://www.nbs.rs/internet/ cirilica/60/60_1/60_1_1.html time of review February, 2014

Hooks, K. (2011). Auditing and Assurance Services: Understanding the Integrated Audit. Danver, USA: John Wiley \& Sons.

International Accounting Standards. IAS 21 "Efekti promena deviznih kurseva" "The Official Gazette of RS" no. 16 / 2008

International Standards on Auditing (2010). Belgrade, Serbia: DPRS. 
Jovković, B. (2010). Primena postupaka uzorkovanja revizora za svrhu testiranja kontrola preduzeća klijenta. Ekonomski horizonti, 12(2), 133-155.

Jovković, B. (2011). Testiranje realnosti ciklusa transakcija i salda računa zaliha i stalne imovine. Ekonomski horizonti, 13(2), 87-105.

Law of Obligations, "The Official Gazzette of the FRY", no. 29/78, 39/85, 45/89 - Resolution CCY and 57/89, "The Official Gazzette of the FRY", no. 31/93 and "The Official Gazzette of the FRY", no. 1/2003 - Constitutional Charter

Law on Accounting and Auditing, "Official Gazzette of RS" no. $46 / 2006$ and $111 / 2009$

Law on Accounting, "The Official Gazzette of RS" no. 62/2013, available at http://www.parlament.rs/upload/archive/files/ lat/pdf/zakoni/2013/2276-13Lat.pdf

Law on Auditing, "The Official Gazzette of RS" no. 62/2013, available at http://www.parlament.rs/upload/archive/files/ lat/pdf/zakoni/2013/2270-13Lat.pdf
Malinić, S. (1999). Organizacija računovodstva. Kragujevac, Republika Srbija: Ekonomski fakultet.

National Bank of Serbia http://www.nbs.rs/internet/ cirilica/60/60_1/60_1_1.html, time of review February, 2014

Pjanić, Z., Stojanović, I., i Jakšić, M. (1994). Ekonomska i poslovna enciklopedija. Beograd, Republika Srbija: Savremena administracija.

Resolution on the contents of the audit report of insurance company's financial statements, "The Official Gazzette of RS" no. 21/2005, $24 / 2005,54 / 2005$

Rittenberg, L., Schwieger, B., \& Johnstone, K. (2008). Auditing: A Business Risk Approach. Mason, USA: Thomson SouthWestern.

Soltani, B. (2007). Auditing - An International Approach. Harlow, England: Prentice Hall.

Whittington, R., \& Pany, K. (2014). Principles of Auditing and Other Assurance Services. New York, USA: McGraw-Hill.

Received on $7^{\text {th }}$ March 2014, after revision, accepted for publication on $17^{\text {th }}$ April 2014

Biljana Jovkovic is an assistant professor at the Faculty of Economics, University of Kragujevac, where she received her doctorate degree. She teaches the subjects: Financial Organization Accounting and Audit of Financial Statements. The key areas of her interest are accounting in insurance companies and banks, audit of financial statements, internal control and internal audit. 


\title{
PRIMENA TEHNIKA PRIKUPLJANJA DOKAZA U ISPITIVANJU OSNOVNIH CILJEVA REVIZIJE U OSIGURAVAJUĆIM DRUŠTVIMA
}

\author{
Biljana Jovković* \\ Ekonomski fakultet Univerziteta u Kragujevcu
}

\begin{abstract}
Nezavisni revizor iznosi mišljenje o finansijskim izveštajima čija je osnovna uloga u smanjenju asimetrije informacija između menadžmenta društava za osiguranje i postojećih i potencijalnih investitora. Smanjenjem informacionog rizika prezentovanih finansijskih izveštaja, revizija omogućuje sigurnije donošenje investicionih odluka korisnika ovih izveštaja. Da bi se ostvarila ova osnovna funkcija revizije, neophodno je da revizori prikupe dovoljno kompetentnih dokaza primenom adekvatnih i relevantnih tehnika ispitivanja. Cilj ovog rada je da ukaže na specifičan položaj revizije kada je klijent osiguravajuće društvo i, s tim u vezi, na potrebu diferenciranja prioritetnosti pojedinačnih revizorskih ciljeva, kao i neophodnosti prilagođavanja implementiranih tehnika prikupljanja dokaza u revizorskom angažmanu kod osiguravajućeg društva, uz istovremeno uvažavanje propisanih uobičajenih procedura koje nameće profesionalna regulativa. U radu je učinjen pokušaj sveobuhvatne analize delotvornosti pojedinačnih tehnika prikupljanja dokaza za potrebe dokazivanja ostvarenosti svakog pojedinačnog cilja revizije, kao i njihova različita primenljivost kod ispitivanja pojedinih bilansnih pozicija u finansijskim izveštajima osiguravajućih društava.
\end{abstract}

Ključne reči: tehnike prikupljanja dokaza, ciljevi revizije, finansijski izveštaji osiguravajućih društava

JEL Classification: G22, M42

\section{UVOD}

Revizorsko mišljenje o finansijskim izveštajima iskazano na osnovu pukog posmatranja prikazanih iznosa i pozicija bez dokaza bilo bi ravno nagađanju, što bi imalo posledice na lica koja bi svoje odluke bazirala na jednom tako izdatom izveštaju. Značaj pribavljanja dokaza je u tome što oni ulivaju poverenje

\footnotetext{
* Korespondencija: B. Jovković, Ekonomski fakultet Univerziteta u Kragujevcu, Đ. Pucara 3, 34000 Kragujevac, Srbija; e-mail: bjovkovic@kg.ac.rs
}

u posao izvršen od strane revizora. Osnovne faze procesa revizije su: definisanje uslova angažmana, planiranje, ocena rizika i funkcionisanje interne kontrole, izvođenje postupaka suštinskog ispitivanja i podnošenje revizorskog izveštaja. Uslovi revizorskog angažmana su precizno definisani $u$ pismu $o$ angažmanu. U njemu su obuhvaćeni: cilj revizije, i obaveze revizora i klijenta. Proces revizije se nastavlja njenim planiranjem u cilju efikasnijeg i efektivnijeg obavljanja. Dokumentuje se plan i program revizije u kojima su sadržani priroda, obim i vreme obavljanja postupaka revizije. U zavisnosti od kvaliteta 
sistema interne kontrole određuje se obim testova i postupaka suštinskog ispitivanja koji će se sprovesti u postupku prikupljanja dokaza (Jovković, 2011, 94). U poslednjoj fazi, revizor izražava svoje mišljenje o finansijskim izveštajima na bazi prikupljenih dokaza. Različitost dokaznog materijala utiče na pouzdanost revizorskog izveštaja. Dokazi treba da budu dovoljni, reprezentativni i pouzdani, što je slučaj ako su oni prikupljeni primenom adekvatnih tehnika prikupljanja u skladu sa revizorskim ciljem čije ostvarenje se testira.

Predmet istraživanja u radu je, upravo, adekvatnost primene pojedinih revizorskih tehnika $\mathrm{u}$ procesu ispitivanja ostvarenosti osnovnih revizorskih ciljeva za pojedinačne bilansne pozicije $u$ finansijskim izveštajima osiguravajućih društava. Revizorje naročito zainteresovan da se uveri da osiguravajuće društvo dosledno primenjuje odgovarajuće računovodstvene politike. Sledeće specifične pozicije zahtevaju posebnu pažnju revizora: rezervisanja na ime šteta, prenosne premije, matematička rezerva osiguranja života, rezervisanja za izravnanje rizika itd. Usled visokog stepena inherentnog rizika koji je svojstven obavljanju ove delatnosti, postoji rizik neotkrivanja nekih značajnih grešaka. Iz ovog razloga revizor je obavezan da planira reviziju u osiguranju sa stavom posebnog profesionalnog skepticizma, prilagođavajući postupke pribavljanja revizorskog dokaza za sve karakteristične bilansne pozicije u osiguranju.

Cilj rada je da se utvrde prioritetni revizorski ciljevi ispitivanja za pojedine bilansne pozicije $u$ finansijskim izveštajima kada je klijent revizije osiguravajuće društvo, i da se u skladu sa opredeljenim ciljevima na koje je stavljen naglasak $\mathrm{u}$ procesu revizorskog ispitivanja preporuče adekvatne i efikasne tehnike prikupljanja dokaznog materijala. Na osnovu izvršene analize ciljeva revizorskog ispitivanja i primenjenih tehnika važno je identifikovati ključne probleme kod implementacije pojedinačnih, uobičajno korišćenih tehnika prikupljanja dokaza, što će omogućiti uočavanje neophodnih modifikacija $u$ njihovoj implementaciji.

Osnovna hipoteza od koje se $u$ radu polazi je da primena pojedinih tehnika prikupljanja dokaza zavisi od pojedinačnih revizorskih ciljeva koji imaju različitu značajnost za pojedine bilansne pozicije kada je klijent osiguravajuće društvo. Osiguravajuća društva su značajne finansijske institucije, pa bi odsustvo dokazivanja ciljeva revizorskog ispitivanja usled primene neadekvatnih tehnika ocenjivanja proizvelo nesigurnost $\mathrm{u}$ istinitost njihovih finansijskih izveštaja. $\mathrm{U}$ skladu sa definisanom osnovnom hipotezom, $\mathrm{u}$ istraživanju analiziraće se da li je primena poznatih tehnika prikupljanja dokaza u procesu revizije frekventnija kod nekih revizorskih ciljeva, ukoliko je klijent osiguravajuće društvo.

Respektujući postavljeni cilj i opredeljeni predmet istraživanja u radu se primenjuju adekvatne metode definisane tematikom istraživanja. Radi razumevanja specifičnosti revizorskog procesa u društvima za osiguranje primenjuje se komparativna analiza primenjenih postupaka i korišćenih tehnika revizije u osiguranju i drugim preduzećima. Koriste se metode dedukcije, analize, sinteze i, naročito, postupaka indukcije, pri čemu se polazi od osnovnih pojedinačnih pretpostavki u cilju donošenja opštih zaključaka. Rad je potkrepljen grafičkim prikazom strukture revizorskih izveštaja prema iznetim mišljenjima $u$ sektoru osiguranja za 2011. i 2012.

Imajući u vidu postavljeni predmet i cilj istraživanja, kao i definisanu hipotezu, u radu se, najpre, analizira regulativa revizorske profesije $\mathrm{u}$ Republici Srbiji. Nakon iznošenja ključnih regulatornih zahteva, pažnja će biti usmerena na osnovne revizorske ciljeve, odnosno, osnovne tvrdnje menadžmenta, čije ostvarenje se ispituje u revizorskom angažmanu. Definisanje ciljeva revizorskog ispitivanja omogućiće razmatranje delotvornosti primenjenih tehnika prikupljanja dokaza koji potvrđuju ili osporavaju istinitost navedenih menadžerskih tvrdnji. Celokupna analiza biće zaokružena iznošenjem strukture revizorskih izveštaja prema iznetim mišljenjima $u$ sektoru osiguranja u 2011. i 2012, što će omogućiti sagledavanje kvaliteta finansijskog izveštavanja $\mathrm{u}$ ovoj oblasti i mogućnosti za unapređenje revizorske profesije u budućnosti.

\section{REGULATIVA REVIZIJE U REPUBLICI SRBIJI}

Profesija revizije $u$ Republici Srbiji uređena je Zakonom o reviziji koji je usvojen 2013. Pre stupanja na 
snagu pomenutog zakona, ova oblast je bila uključena zajedno sa računovodstvom u jedinstvenu celinu koju je uređivao Zakon o računovodstvu i reviziji (Zakon o računovodstvu i reviziji, "Službeni glasnik $\mathrm{RS}^{\prime}$ br. 46/2006.). Stupanjem na snagu novog zakona, ove dve oblasti su razdvojene u dva posebna zakona. Prema važećem Zakonu, zakonska revizija je:

„revizija koja je obavezna za redovne godišnje finansijske izveštaje velikih i srednjih pravnih lica razvrstanih u skladu sa zakonom kojim se uređuje računovodstvo, javnih društava u skadu sa zakonom kojim se uređuje tržište kapitala nezavisno od njihove veličine, kao i svih pravnih lica, odnosno preduzetnika čiji poslovni prihod ostvaren $u$ prethodnoj poslovnoj godini prelazi 4.400 .000 eura u dinarskoj protivvrednosti. Zakonska revizija obavlja se u skladu sa ovim zakonom, drugim zakonima koji uređuju obaveznu reviziju finansijsih izveštaja kod pojedinih pravnih lica, MSR i Kodeksom profesionalne etike revizora" (Zakon o reviziji, čl. 21, stav 1).

Društva za reviziju su i sama korisnici usluga osiguranja kod osiguravajućih društava. Naime, prema odredbi Zakona „Društvo za reviziju dužno je da se osigura od odgovornosti za štetu koju učini pravnom licu kod koga obavlja reviziju odnosno trećem licu u slučaju povrede ugovora o reviziji, odnosno povrede pravila obavljanja revizije“ (Zakon o reviziji, čl. 18.).

\section{OSNOVNI CILJEVI REVIZIJE FINANSIJSKIH IZVEŠTAJA}

Opšti cilj revizije finansijskih izveštaja osiguravajućih društava, preduzeća i drugih klijenata jeste izražavanje mišljenja o tome da li su finansijski izveštaji po svim materijalno značajnim aspektima pravilno prezentovani, odnosno, sačinjeni u skladu sa definisanim okvirom finansijskog izveštavanja (Zakon o reviziji, čl. 30, tačka 3). Da bi izrazio mišljenje o istinitosti finansijskih izveštaja osiguravajućeg društva neophodno je da se revizor uveri $u$ istinitost svih bilansnih pozicija $u$ finansijskim izveštajima i obelodanjivanja ostalih relevantnih informacija od stranemenadžmenta. Prema tome, ostvarenje osnovnog cilja revizije i ispunjenje njene primarne misije postiže se dekomponovanjem opšteg revizorskog cilja na skup izvedenih ciljeva, čijom se uspešnom realizacijom stvaraju uslovi za izražavanje kompetentnog mišljenja. Menadžment osiguravajućeg društva je primarno odgovoran za evidentiranje, obradu, sumiranje i prezentiranje finansijskih informacija (Jovković, 2010, 152). Samim tim, posebni ciljevi revizije se odnose na eksplicitne i implicitne tvrdnje menadžmenta koje su vezane za prezentirane bilansne pozicije. Tvrdnjom se smatra izjava menadžmenta data eksplicitno ili na drugi način, koja je ugrađena $u$ finansijske izveštaje i odnosi se direktno na pravilnost prezentiranja ključnih bilansnih pozicija u tim izveštajima. Revizorskim ispitivanjima neophodno je ustanoviti ostvarenost, ili odsustvo, ispunjenja navedene tvrdnje menadžmenta. Ostvarenjem izvedenih ciljeva koji su vezani za potrebu provere pojedinačnih bilansnih pozicija, stvaraju se uslovi za ostvarenje osnovnog cilja - davanje mišljenja o istinitosti i objektivnosti finansijskih izveštaja.

Izvedeni ciljevi revizije čije ostvarenje je neophodno dokazati prikupljenim dokazima su (Rittenberg, Schwieger \& Johnstone, 2008, 152):

- postojanje ili dešavanje,

- potpunost ili kompletnost,

- prava (vlasništvo) i obaveze,

- vrednovanje ili alokacija,

- tačnost,

- razgraničenje i

- prezentacija i obelodanjivanje.

Prvi izvedeni cilj revizije finansijskih izveštaja osiguravajućeg društva odnosi se na ispitivanje i dokazivanje tvrdnje menadžmenta da prezentirana imovina, kapital i obaveze društva zaista postoje, odnosno, prikazani prihodi, rashodi i dobici ili gubici su se uistinu desili u datom obračunskom periodu. Tvrdnja postojanja dokazuje se kako za bilansne pozicije koje imaju materijalni oblik postojanja, poput osnovnih sredstava, gotovine, zemljišta, hartije od vrednosti i sl, tako i za bilansne pozicije koje su nematerijalne prirode, poput potraživanja za ugovorene premije, potraživanja za učešća u šteti od saosiguravača i reosiguravača, obaveza za štete 
iz osiguranja i sl. Primenjuju se različite tehnike prikupljanja dokaza u zavisnosti od toga da li imovina osiguravajućeg društva ima materijalni ili nematerijalni oblik. Obilaskom poslovnih prostorija revizor će se uveriti u postojanje građevinskih objekata, dok za uveravanje o postojanju potraživanja po osnovu premija biće neophodno tražiti potvrdu druge ugovorne strane, što znači da će se primeniti tehnika konfirmacije. Primena ove tehnike najpre zahteva uvid u ugovorena osiguranja, zatim, pregled prispelih IOS-a i slanje zahteva za konfirmaciju osiguraniku kako bi se steklo uverenje da iskazana potraživanja zaista postoje. Ova tehnika prikupljanja dokaza obezbeđuje uveravanje $\mathrm{u}$ ostvarenost ovog revizorskog cilja ali ne istovremeno i nekog drugog cilja poput pravilnog vrednovanja za čije ispitivanje je potrebno primeniti drugu adekvatnu tehniku. Navedena tvrdnja može biti pogrešno prikazana ukoliko se $u$ iznos realizacije uključi i deo fiktivne realizacije, ili ukoliko su u vrednost bilansne pozicije uključene i transakcije koje su se desile posle isteka obračunskog perioda. Osnovna briga revizora kada analizira istinitost tvrdnje menadžmenta o postojanju ili dešavanju u osiguravajućem društvu nasuprot klijentima iz drugih delatnosti, odnosi se na mogućnost precenjivanja salda pojedinih bilansnih pozicija kroz uključivanje bilansnih stavki koje ne egzistiraju ili uključivanje efekata transakcija koje se istinski nisu ni dogodile (iskazivanje fiktivnih potraživanja za premije, iskazivanje potraživanja za udele u šteti od saosiguravača kada takva prava ne postoje i sl. samo su neki od primera precenjivanja bilansnih pozicija). Na računima grupe 24, osiguravajuće društvo iskazuje gotovinske ekvivalente, gotovinu, neposredno unovčive hartije od vrednosti i depozite po viđenju. $S$ obzirom na neizvesnost nastanka rizika u osiguravajućim organizacijama nameće se potreba posedovanja značajnih novčanih sredstava kako bi bile u prilici da servisiraju svoje eventualne obaveze prema osiguranicima. Cilj postojanja je u središtu revizije salda novčanih sredstava i za testiranje njegovog ostvarenja revizor je primarno zainteresovan, dok ispitivanje ostvarenja ostalih ciljeva ima sekundarni karakter, i oni ne predstavljaju poseban problem revizoru $\mathrm{u}$ procesu testiranja. Jedan od osnovnih postupaka uveravanja $u$ postojanje navedenih novčanih sredstava je prisustvovanje popisu gotovine.
Prisustvovanjem nezavisnog revizora popisu i uvidom u zapisnik komisije za popis gotovine, gotovinskih ekvivalenata i hartija od vrednosti stiču se dokazi o postojanju navedenih sredstava, kao i o eventualnim razlikama između popisnog i knjigovodstvenog stanja.

Potpunost predstavlja cilj revizije koji se odnosi na potrebu da se u finansijskim izveštajima prikažu sve ekonomske transakcije i iznosi koji su se desili $\mathrm{u}$ osiguravajućem društvu u periodu na koji se finansijski izveštaj odnosi. Kompletnost podrazumeva prikazivanje svih prihoda i rashoda, promena na kapitalu, obavezama i imovini koje su se dogodile u periodu izveštavanja (Eilifsen, Messier, Glover \& Prawitt, 2014, 129). Dakle, menadžment tvrdi da su u bilansima uključene sve obaveze, imovina, kapital, prihodi, rashodi, gubici i dobici. Izvođenjem primerenih postupaka, prikupljanja dokaza potrebno je dokazati da li su sve transakcije i računi koji je trebalo da budu uključeni u finansijske izveštaje zaista u njih i uključeni, kao i da ne postoji neobelodanjena imovina, obaveze ili izostavljene transakcije. Kada se vrši revizija u osiguravajućem društvu naglašena je neophodnost sticanja uverenja da bilans uspeha osiguravajućeg društva uključuje sve transakcije prodaje usluga osiguranja u obračunskom periodu, $\mathrm{i}$ da ne postoje izostavljene transakcije po tom osnovu. Provera tvrdnje kompletnosti usmerena je na ispitivanje postojanja eventualne potcenjenosti nekih bilansnih pozicija, odnosno, utvrđivanje da li postoji izostavljanje nekih bilansnih pozicija ili efekata nekih transakcija koje je trebalo da budu uključene u bilansne izveštaje (izostavljanje prezentiranja obaveza po osnovu odštetnih zahteva iz osiguranja, izostavljanje iskazivanja rezervisanja po raznim osnovama koja je neophodno sprovesti, itd.). Otkriti izostavljene transakcije ili delove bilansne pozicije revizorskim postupcima mnogo je teže nego testirati tvrdnju postojanja s obzirom na to da je početak ispitivanja šta treba da bude proknjiženo, a ne šta je proknjiženo. Najčešće izostavljeno obuhvatanje transakcija nema materijalni trag $u$ evidencijama osiguravajućeg društva, a neretko ne postoji dokumentacija koja upućuje na nastanak poslovne promene. Kada je izostavljanje transakcija uočeno, onda problem tačnosti iznosa koji su trebali biti uključeni implicira netačnost tvrdnji menadžmenta o tačnosti i vrednovanju. 
Ovaj cilj ima posebnu važnost $\mathrm{u}$ reviziji klijenata iz osiguranja, jer nekompletno prikazivanje prodaje usluga osiguranja povlači dve posledice: potcenjivanje prihoda $u$ momentu prodaje i nastanak obaveza po štetnim zahtevima kada se ostvari rizik. Efekat negativnih posledica je dvostruk, izostanak knjiženja prihoda i nastanak rashoda nasuprot kojih ne stoje obračunati prihodi. Za dokazivanje ispunjenosti cilja kompletnosti $u$ reviziji se koristi tehnika inspekcije dokumenata, i to u narednom obračunskom periodu, najčešće za transakcije isplate i naplate gotovine. Pregledom transakcija u narednom periodu moguće je otkriti isplate gotovine po osnovu obaveza koje nisu bile obuhvaćene na dan bilansa, a trebale su biti iskazane, ili je došlo do naplate gotovine po osnovu potraživanja od, na primer, saosiguravača, koja nisu bila iskazana na dan bilansa. Razlog pomeranja perioda istraživanja na naredni perod jeste taj što u slučaju neostvarenosti cilja kompletnosti ne postoji materijalni trag u računovodstvu koji potvrđuje da postoje realni poslovni događaji koji su trebali bili obuhvaćeni u evidenciji. Usled toga, testiraju se transakcije narednog perioda, kako bi se izveli zaključci retroaktivno o postojanju potcenjenosti.

Izvedeni revizorski cilj prava i obaveze odnosi se na potrebu uveravanja revizora da je imovina vlasništvo osiguravajućeg društva, odnosno, da su obaveze dužnička obaveza društva u određenom obračunskom periodu. Osiguravajuće društvo ima iskazane depozite po viđenju i oročene depozite kod poslovnih banaka u bilansu pošto deo tehničkih rezervi drži u likvidnom obliku, pa je kod ovih pozicija prioritetno uveriti se da društvo ima pravo vlasništva nad iskazanim sredstvima. U vlasništvo depozita po viđenju kod poslovnih banaka i postojanje eventualnih ograničenja u raspolaganju i korišćenju (data založna izjava) revizor se uverava koristeći osnovnu revizorsku tehniku konfirmacije nezavisne treće strane, $\mathrm{u}$ ovom slučaju banke. Na osnovu dobijenih konfirmacija ukoliko su banke potvrdile revizoru iskazane iznose, može se izvesti zaključak da navedena sredstva postoje, vlasništvo su osiguravajućeg društva i tačno su iskazana. Ovim putem mogu se, istovremeno, steći uverenja $\mathrm{u}$ ostvarenost više ciljeva revizije. Pravo vlasništva se dokazuje i za ostale oblike imovine, na primer, za zemljište - izvodom iz katastra, za opremu - na bazi kupoprodajnog ugovora itd. U slučaju prodaje usluga osiguranja kada osiguranik ne uplati odmah pripadajuću premiju, osiguravajuće društvo na osnovu dužničko poverilačkih odnosa nastalih po osnovu osiguranja ima pravo da iskaže pripadajuće potraživanje kao imovinu društva (Zakon o obligacionim odnosima, član 148, tačka 1). Prema učinjenim zapisnicima o nastaloj, prijavljenoj i priznatoj šteti osiguranika, po osnovu realizacije osiguranog rizika, osiguravajuće društvo ima obavezu isplate štete, pa, stoga, prikazuje po ovom poslu nastale obaveze. Tvrdnje menadžmenta o pravima i obavezama društva tangiraju samo pozicije bilansa stanja i primenom adekvatnih tehnika (konfirmacija $\mathrm{i}$ inspekcija dokumenata) revizor se uverava $u$ osnovanost navedenih tvrdnji.

Tvrdnja menadžmenta o vrednovanju i alokaciji odnosi se na iskazivanje imovine, obaveza, kapitala, prihoda i rashoda u finansijskim izveštajima društva u odgovarajućim iznosima. Kada je reč o osiguravajućem društvu izuzetno je značajno da pojedini elementi finansijskih izveštaja budu pravilno vrednovani, odnosno, da ne postoje potcenjivanja ili precenjivanja bilansnih pozicija. Poseban akcenat $u$ procesu revizije stavlja se na potraživanja iz poslovnog odnosa, koja su uključena u bilans stanja i potrebno je dokazati da odražavaju realno naplativ iznos. Područje koje revizor proverava sa posebnim profesionalnim skepticizmom jeste ispravan obračun ispravke vrednosti potraživanja koji direktno utiče i opredeljuje istinitost iskazanih potraživanja. Iskazivanje obaveza po osnovu rezervisanja za potrebe izjednačavanja obaveza društva za preuzete rizike u nizu obračunskih perioda često je prisutno i svojstveno osiguravajućim društvima, pa je važno pravilno iskazati vrednosti navedenih obaveza, kako ne bi došlo do njihovog potcenjivanja ili precenjivanja. Dugoročna rezervisanja se obračunavaju u osiguravajućim društvima sa ciljem stvaranja pokrića za preuzete rizike. Najvažniji cilj je uveriti se u njihovo ispravno vrednovanje, odnosno, da li su precenjena ili potcenjena. Potcenjivanje dugoročnih rezervisanja imalo bi za posledicu iskazivanje bolje finansijske situacije $\mathrm{u}$ društvu $\mathrm{u}$ posmatranom periodu, što bi u budućnosti moglo da prouzrokuje zapadanje društva $u$ nelikvidnost ili nesolventnost, ako bi nastupili rizični događaji. 
Kada se dugoročna rezervisanja precene, onda se stvaraju latentne rezerve $u$ društvu, odnosno, većim obračunom rezervisanja $u$ tekućem periodu na teret rashoda iskazuje se manji periodični rezultat od onog koji uistinu prema stvarnom stanju stvari treba da bude. Ukoliko bi se rezervisanja u narednom periodu pravilno obračunala, višak prvobitno obračunatih rezervisanja ukinuo bi se u korist prihoda što bi značilo premeštanje dela dobiti iz jednog $\mathrm{u}$ drugi obračunski period, odnosno, njegovo pogrešno iskazivanje u nizu obračunskih perioda. $U$ procesu revizije o pravilnosti vrednovanja i iskazivanja dugoročnih rezervisanja za izravnanje rizika neophodno je uveriti se iz još jednog, ne manje značajnog razloga. Naime, ova rezervisanja predstavljaju deo tehničkih rezervi osiguravajućeg društva pored prenosne premije i rezervisanih šteta. Tehničke rezerve se formiraju u svrhu zaštite interesa osiguranika i predstavljaju rezerve deponovane $\mathrm{u}$ pojedine propisane oblike ulaganja kako bi osiguravajuća društva $u$ svakom momentu svog poslovanja bila u mogućnosti da odgovore na odštetne zahteve proisteke iz preuzetih rizika ugovorom o osiguranju. Osnovna tehnika koja se koristi prilikom ispitivanja vrednovanja rezervisanja jeste računska kontrola upotrebom akturske metode obračuna datih rezervisanja. U implementaciji ove tehnike, za razliku od drugih revizorskih angažmana, neophodno je da revizor poseduje znanja iz aktuarstva, kako bi procena bila validna.

Tačnost je tvrdnja koja se odnosi na matematičku tačnost transakcija koje se evidentiraju u finansijskim izveštajima, kao i na pravilno zbrajanje i knjiženje tih transakcija u sintetičkoj evidenciji. Na primer, neophodno je uveriti se $u$ matematičku tačnost obračuna raspodele bruto premije na deo koji se odnosi na tehničku premiju i režijski dodatak, a zatim, i raspodelu pripadajućih iznosa premije periodima trajanja osiguranja. Slično ovom, treba ispitati tačnost obračuna nastalih obaveza po osnovu šteta koje su prijavili osiguranici i koja je prijavljena a likvidirana ili prijavljena a nelikvidirana u obračunskom periodu. Posebna pažnja revizora usmerena je na ispitivanje pravilnosti: matematičkog obračuna prenosnih premija, matematičkih rezervi i rezervisanja za izjednačavanje rizika. Ispituje se da li je pravilno izvršen obračun i $u$ propisanim oblicima evidencije obuhvaćeno rezervisanje. Najčešće se koristi tehnika računske kontrole. Na primer, kada klijent revizije poseduje sredstva na deviznom računu $u$ procesu ispitivanja ove bilansne pozicije potrebno je uveriti se da su devizna sredstva pravilno preračunata $\mathrm{u}$ dinarsku protivvrednost i utvrđene kursne razlike pravilno knjigovodstveno obuhvaćene (Međunarodni računovodstveni standardi, 112). Postupak ispitivanja započinje uvidom $u$ strukturu sredstava na deviznim računima, procenom sredstva u dinarskoj protivvrednosti po srednjem kursu Narodne banke Srbije (NBS) na dan bilansa, shodno odredbama zakona (Zakon o računovodstvu, člana 6. stav 5).

Razgraničenje kao cilj revizije podrazumeva da su sve transakcije koje su se desile blizu datuma periodičnog obračuna rezultata evidentirane i prikazane u periodu na koji se zaista i odnose u skladu sa zahtevom osnovnog računovodstvenog principa uzročnosti sučeljavanja pripadajućih rashoda pripadajućim prihodima. Ovaj problem je izrazito prisutan $\mathrm{u}$ osiguravajućim društvima s obzirom na to da postoji neslaganje između vremena zaključenja ugovora o osiguranju (trajanja vremena osiguranja) i perioda obračuna rezultata. S tim u vezi, ključni problem je utvrditi pravilnost razgraničenja naplaćene premije na pripadajuću zarađenu premiju i nezarađenu prenosnu premiju koja se odnosi na buduće obračunske periode. Pogrešna raspodela premije između zarađenog i nezarađenog dela ima za posledicu nekompletno iskazivanje prihoda u različitim obračunskim periodima što rezultira pogrešnim iskazivanjem ostvarenog periodičnog rezultata kao i pogrešno iskazivanje sume bilansa stanja ukoliko su prenosne premije kao pasivna pozicija potcenjene ili precenjene. Tehnikom inspekcije dokumenata potrebno je izvršiti analizu obračuna prenosne premije svake vrste osiguranja koje društvo ima u svom portfelju, pregled analitičke evidencije i razgraničenja premije na zarađeni i prenosni deo, te sprovedenih knjiženja u računovodstvu po osnovu izvršenog obračuna. U postupku analize uzorkovanih dokumenata, revizor će ispitati podatke na osnovu kojih je izvršen obračun, a to su: visina premije osiguranja, datum početka i isteka osiguravajućeg pokrića, broj dana trajanja osiguranja, broj dana trajanja osiguranja nakon periodičnog obračuna, visina osiguravajućeg pokrića - rizika na početku trajanja osiguranja, visina osiguravajućeg pokrića - rizika na kraju trajanja osiguranja i sl. 
Cilj prezentacija i obelodanjivanje odnosi se na uveravanje da su sve komponente finansijskih izveštaja pravilno klasifikovane i opisane, kao i da su u napomenama uz finansijske izveštaje učinjena neophodna obelodanjivanja. Ukoliko postoje određena ograničenja nad imovinom ili raspolaganja pojedinim njenim oblicima, ako postoje informacije o obavezama koje mogu biti relevantne za korisnike finansijskih izveštaja, onda takve činjenice moraju biti obelodanjene. Primenom tehnike ispitivanja menadžmenta, revizor se uverava $u$ ostvarenost prezentacije i zahtevanih obelodanjivanja i donosi odluku o zadovoljenju ovog cilja finansijskim izveštavanjem osiguravajućeg društva.

Kvalitet finansijskih izveštaja osiguravajućeg društva uslovljen je ne samo sastavljanjem izveštaja na kraju obračunskog perioda, već i samim obuhvatanjem svake poslovne transakcije $\mathrm{u}$ toku obračunskog perioda. Tačnije, svaka poslovna transakcija ima svoj dokumentacioni, evidencioni i izveštajni aspekt (Malinić, 1999, 153). Relevantnom poslovnom promenom smatra se samo ona transakcija koju potvrđuje dokument kao pisana isprava o njenom nastanku (Pjanić, Stojanović i Jakšić, 1994, 1277). Ispravna dokumenta, kao osnov evidencije, daju pečat ukupnom kvalitetu računovodstvenog sistema društva i predstavljaju nit koja se provlači kroz evidencioni aspekt do samog izveštavanja determinišući istinitost i objektivnost izveštaja. Izveštajni aspekt poslovnih transakcija odnosi se na potrebu sistematizacije podataka $u$ poslovnim knjigama i njihove prezentacije $\mathrm{u}$ propisanim obrascima. Prema Zakonu o računovodstvu (2013, član 2, stav 1, tačka 7), osiguravajuća društva su dužna da sastavljaju godišnji zaključak koga čine: bilans stanja, bilans uspeha, izveštaj o ostvarenom rezultatu, izveštaj o tokovima gotovine, izveštaj o promenama na kapitalu, napomene uz finansijske izveštaje. Ovi izveštaji su predmet zakonske revizije i revizor daje mišljenje o njihovoj istinitosti i objektivnosti $u$ revizorskom izveštaju, ostvarujući osnovni cilj revizije.

\section{TEHNIKE PRIKUPLJANJA DOKAZA}

Proces revizorskih ispitivanja je pažljivo planirana aktivnost koja ima za cilj određivanje aktivnosti koje će se tokom revizorskog angažmana sprovoditi. Najvažniji parametar koji revizor tokom planskih aktivnosti treba da izrazi je revizorski rizik koji je spreman da prihvati u angažmanu. On se koristi kako bi se definisale adekvatne tehnike prikupljanja dokaza i sprovođenja postupaka ispitivanja koja će voditi ostvarenju osnovnih revizorskih ciljeva.

Tehnike koje se koriste u pribavljanju dokaza su (Whittington \& Pany, 2014, 143):

- inspekcija,

- posmatranje,

- ispitivanje i konfirmacija,

- računska kontrola i

- analitički postupci.

Inspekcija (pregled) dokumenata i izveštaja sastoji se od ispitivanja izveštaja i dokumenata, bilo da su interna ili eksterna, u papirnom ili elektronskom obliku. Pregledom dokumenata revizor stiče precizna saznanja o uslovima u ugovorima koje je zaključilo osiguravajuće društvo ili odredbama polisa osiguranja koje je izdalo. Neka dokumenta predstavljaju neposredne dokaze revizije o postojanju sredstava. Na primer, dokaz predstavlja finansijski instrument kao što je akcija ili obveznica i njihovim pregledom se stiče uverenje o postojanju ovih finansijskih sredstava. Međutim, pregled ovakvih dokumenata ne može neminovno obezbediti dokaz revizije o vrednosti sredstva čije postojanje je dokazano. Tokom inspekcije revizor može proceniti istinitost dokumenata, ili možda otkriti postojanje promenjenih ili sumnjivih pozicija na samom dokumentu. Dva važna procesa ispitivanja $\mathrm{u}$ reviziji povezana sa inspekcijom dokumenata su potvrđivanje i traganje. Potvrđivanje uključuje izbor pozicija $u$ finansijskom izveštaju i pregled dokumenata koji predstavljaju osnovu za knjiženja transakcija vezanih za tu bilansnu poziciju kako bi se odredila validnost i tačnost učinjenih knjiženja. Na primer, kada testira pojavljivanje prodaje usluga osiguranja revizor može odabrati transakcije u dnevniku prodaje i potvrditi transakcije pregledom polise osiguranja. Potvrđivanje je obimno korišćeno za otkrivanje precenjivanja $u$ finansijskim izveštajima. 
Dakle, ovo je važna procedura u sticanju dokaza koji se odnose na tvrdnje postojanja ili pojavljivanja. U traganju revizor odabira dokumenta koja su kreirana kada su transakcije nastale i analizira da li je dokument ispravno proknjižen $u$ evidenciji i sadržan u poziciji finansijskog izveštaja. U traganju, pravac testiranja je suprotan onom koji se koristi pri potvrđivanju, polazi se od dokumenata ka finansijskom izveštaju, tako što se rekonstruiše izvoran tok podataka kroz računovodstveni sistem. Na primer, kada testira potpunost prodaje usluga osiguranja, revizor može odabrati uzorak polisa osiguranja i pratiti transakciju tokom knjiženja $u$ dnevniku prodaje i glavnoj knjizi. Pošto ova procedura obezbeđuje uveravanje da su podaci iz izvornih dokumenata uključeni u konačna salda računa, posebno je koristan za otkrivanje suzdržanosti u finansijskim izveštajima. Ovo je važna procedura u sticanju dokaza koji se odnose na tvrdnju potpunosti. Pregled ili inspekcija može da se koristi i za sticanje dokaza o fizički prisutnim sredstavima u osiguravajućim društvima. Pregled vidljivih opipljivih sredstava obezbeđuje revizoru neposredna lična saznanja o njihovom postojanju i fizičkom stanju. Iako pregled vidljivih sredstava, kao što je posmatranje opreme, poslovnih prostorija, transportnih sredstva itd. obezbeđuje čvrste dokaze o tvrdnji postojanja, ova procedura ne obezbeđuje dokaz o pravima društva nad sredstvima.

Posmatranje je tehnika koja se sastoji u nadgledanju procesa ili postupaka koje obavlja neko drugo lice, na primer, kod popisa zaliha. Opservacija ili posmatranje odnosi se na posmatranje postojećih načina ili postupaka izvedenih od strane drugog. Aktivnost može biti rutinski obrađena $u$ određenoj vrsti transakcije kao, na primer, kod prijema gotovine videti da li su zaposleni izveli njihove dužnosti u saglasnosti sa politikama i procedurama kompanije. Posmatranje je posebno važno kada se stiče razumevanje interne kontrole. Kroz ova posmatranja, revizor stiče neposredna lična saznanja koja se odnose na ciljeve revizije. Revizor treba da bude pažljiv kada procenjuje pouzdanost dokaza revizije stečenih kroz posmatranje, jer je ono ograničeno usmereno $u$ vremenu $u$ kojem se izvodi. Na primer, kada revizor izvodi opservaciju interne kontole, dokazi su ograničeni ukazivanjem na funkcionisanje u vremenu posmatranja, odnosno, klijentov personal može primenjivati najbolje ponašanje u skladu sa procedurama interne kontrole kada je revizorski tim prisutan i vrši opservaciju izvođenja nekih poslovnih transakcija.

Ispitivanje je tehnika pribavljanja informacija od zaposlenih $\mathrm{u}$ tom pravnom licu ili od eksternih stručnjaka. Ispitivanje se sastoji $u$ traženju informacija od dobro obaveštenog osoblja klijenta, bilo u finansijskom ili nefinansijskom sektoru. Često je dopunski izvedeno sa drugim procedurama revizije. Sprovodi se kod pribavljanja dokaza o funkcionisanju sistema internih kontrola. Kod revizije računovodstvenih procena nužno je pribaviti mišljenje ovlašćenog aktuara radi sticanja sigurnosti da su procene rezervisanja pravilno izvršene. Ispitivanje može biti formalnog (pisanog) i neformalnog (usmenog) karaktera. Veću vrednost imaju pisane izjave zbog lakšeg dokazivanja i pozivanja na njih. Odgovori dobijeni ispitivanjem mogu obezbediti revizoru informacije koje prethodno nije posedovao ili koje potvrđuju ostale dokaze. Na primer, delotvorna ispitivanja mogu upućivati revizora da označi neočekivan rizik materijalne greške, ili ispitivanje može potvrditi revizorovo razumevanje klijentove interne kontrole. Odgovori mogu obezbediti informacije koje se razlikuju značajno od drugih dokaza koje je revizor stekao. Na primer, ispitivanja zaposlenih $\mathrm{u}$ računovodstvenom odeljenju mogu revizoru pružiti saznanja o postojanju ignorisanja internih kontrola od strane menadžera. U tom slučaju, ispitivanje obezbeđuje smernicu za revizora da prilagodi ili izvede dodatne procedure revizije. Pouzdanost dokaza revizije stečenih ispitivanjem je pod uticajem umešnosti, poznavanja i iskustva revizora $u$ izvođenju ispitivanja $\mathrm{s}$ obzirom na to da revizor analizira $\mathrm{i}$ ocenjuje odgovore tokom izvođenja samog ispitivanja i poboljšava sledeća pitanja prema upravo dobijenim odgovorima.

Konfirmacija predstavlja tehniku dolaženja do potvrde informacija sadržanih u finansijskim izveštajima obraćanjem trećim licima nezavisnim od društva koje je klijent $u$ reviziji. To je proces sticanja reprezentativih informacija o postojećim uslovima neposredno od trećeg lica. Ovim dolazimo do informacija o postojanju, precenjenosti ili potcenjenosti aktive osiguravajućeg društva. Zahtev za potvrdu salda koji je proistekao iz 
ugovornog odnosa osiguravajućeg društva i njegovih osiguranika, finansijskih organizacija i ostalih trećih lica sastavlja se u pisanoj formi i dostavlja trećim licima po izboru samog revizora. Kada je reč o primeni ove tehnike kod osiguravajućeg društva važno je da revizor u potpunosti kontroliše: izbor stavki koje će biti predmet potvrde treće strane, izradu zahteva za konfirmaciju kao i kontrolu samog procesa slanja zahteva trećim licima. Odgovor na konfirmaciju treća strana obavezno upućuje direktno na adresu revizora. U praksi se koriste dve vrste konfirmacije: pozitivna i negativna (Međunarodni standardi revizije, 215). Pozitivnom konfirmacijom se od treće strane zahteva dostavljanje odgovora na zahtev nezavisno od toga da li je tražena informacija tačna ili ne, tj. da li postoji potvrda traženog iznosa ili je prisutno odstupanje $\mathrm{u}$ iskazanom iznosu. Negativnom konfirmacijom zahteva se odgovor od treće strane jedino ukoliko postoji odstupanje u iskazanom iznosu. Veću sigurnost daje korišćenje pozitivne konfirmacije s obzirom na to da treća strana u svakom slučaju odovara na zahtev upućen od strane eksternog revizora. Konfirmacije se koriste $\mathrm{u}$ reviziji pošto je dokaz objektivan i dolazi iz nezavisnog izvora.

Računska kontrola ili preračunavanje se odnosi na proveru matematičke tačnosti dokumenata ili evidencija. Revizori obično koriste revizorske software za izvođenje preračunavanja za analitičke račune potraživanja i slaganje sa sumom u glavnoj knjizi. Ovo je često važna početna procedura. Na primer, revizor najpre želi da bude siguran da se pojedinosti analitike računa potraživanja za premije slažu sa stanjem glavne knjige pre nego što se odluči da koristi slanje konfirmacije.

Analitički postupci obuhvataju analizu značajnih pokazatelja i trendova, uključujući i istraživanje fluktuacija i odnosa koji nisu konzistentni sa drugim relevantnim informacijama ili koji odstupaju od očekivanih iznosa. Može se vršiti poređenje dobijenih izračunatih vrednosti sa vrednostima ostvarenim u prethodnim periodima, planiranim veličinama ili sa ostvarenim vrednostima drugih osiguravajućih društava. Analitičke procedure odnose se na procenu finansijskih informacija navedenih $\mathrm{u}$ izveštajima društva na osnovu proučavanja odnosa između finansijskih i nefinansijskih podataka. Analitički postupci mogu se koristiti u fazi planiranja revizije, u fazi prikupljanja suštinskih dokaza i u fazi opšteg pregleda na kraju revizije. Analitičke procedure se uopšteno koriste za razvijanje očekivanja za iznose u finansijskim izveštajima $\mathrm{i}$ ocenu prihvatljivosti finansijskih izveštaja u tom smislu. Ove procedure se zasnivaju na pretpostavci da će se uočena uslovljenost između podataka nastaviti i ubuduće, ukoliko neke posebne okolnosti ne dovedu do promene $\mathrm{u}$ trendovima. Neuobičajene transakcije ili poslovni događaji, promene računovodstvenih politika, promene $\mathrm{u}$ poslovanju, greške i nezakonite radnje, nastanak slučajnih događaja mogu poslužiti kao primeri nastanka posebnih okolnosti koji dovode do diskontinuiteta uočenih trendova. Analitički postupci mogu biti u vidu analitičkog pregleda ili analize. Analitički pregled se odnosi na potrebu sagledavanja pojedinačne dokumentacije koja svedoči, npr. kod plasmana osiguravajućih organizacija, o sigurnosti izvršenog plasmana i predstavlja suštinsko ispitivanje ove bilansne pozicije. Analitičkim pregledom sadržaja prihoda po osnovu premije osiguranja utvrđuje se postojanje koncentracije rizika u portfelju osiguranja, koncentracija na određene geografske oblasti ili osiguranike. Analiza se odnosi na izračunavanje pokazatelja i trendova na osnovu podataka iz izveštaja osiguravajućih društava. Poređenjem dobijenih rezultata sa planiranim rezultatima prethodnog perioda ili kretanjem u grani, izvode se odgovarajući zaključci.

Zahvaljujući dostignutom stepenu razvoja informacionih tehnologija i software-a, moguće je primenjivati mnoge tehnike prikupljanja dokaza $\mathrm{u}$ procesu revizije upotrebom prilagođenih software-a za potrebe revizije. Kompjuterski razvijene tehnike revizije (CATT) koriste software revizije kako bi se obavile mnoge od navedenih tehnika prikupljanja dokaza (Boynton \& Johnson, 2006, 246). Dokazi mogu biti različitog stepena pouzdanosti, što zavisi od raspoloživosti dokaza, kao i od načina njegovog kreiranja, evidentiranja i korespondencije dokumenata kao što je prikazano na Slici 1.

Najpouzdaniji izvor dokaza za revizora u postupku ispitivanja finansijskih izveštaja osiguravajućeg društva pruža korišćenje tehnike konfirmacije s obzirom na to da osiguravajuća društva značajan iznos 


\begin{tabular}{|c|c|}
\hline Najpouzdaniji & primeri \\
\hline $\begin{array}{c}\text { Eksterno stvorena dokumenta } \\
\text { poslata direktno revizoru }\end{array}$ & $\begin{array}{l}\text { Bankarski izveštaji } \\
\text { Konfirmacije }\end{array}$ \\
\hline $\begin{array}{l}\text { Eksterno stvorena dokumenta } \\
\text { zadržana kod klijenta }\end{array}$ & $\begin{array}{l}\text { Fakutre dobavljača } \\
\text { Izvodi banaka }\end{array}$ \\
\hline $\begin{array}{l}\text { Interno stvorena dokumenta } \\
\text { poslata trećoj strani }\end{array}$ & $\begin{array}{l}\text { Priznanice o uplati } \\
\text { otpremnice }\end{array}$ \\
\hline $\begin{array}{l}\text { Interno stvorena dokumenta koja } \\
\text { se nalaze kod klijenta }\end{array}$ & $\begin{array}{l}\text { Kopije prodatih faktura, } \\
\text { nabavne porudžbenice }\end{array}$ \\
\hline Najmanje pouzdani & primeri \\
\hline
\end{tabular}

Slika 1 Uticaj kretanja dokumenata na pouzdanost dokaza

Izvor: Cosserat \& Rodda, 2009, 167

sredstva drže u gotovinskom obliku radi namirenja nastalih šteta. Najmanje pouzdan dokaz pružaju dokumenta o proceni štete $\mathrm{s}$ obzirom na to da su interno kreirana u osiguravajućem društvu i osnov su za knjiženje najvažnijih rashoda - rashoda po osnovu naknada štete, koji su i najveći po učešću u ukupnim poslovnim rashodima.

\section{REVIZORSKA MIŠLJENJA OSIGURAVAJUĆIM DRUŠTVIMA U REPUBLICI SRBIJI ZA 2011. I 2012.}

Revizor podnosi izveštaj u kome iznosi svoje mišljenje o istinitosti i objektivnosti finansijskih izveštaja. Mišljenje revizora može biti: pozitivno, mišljenje sa rezervom, uzdržavanje od mišljenja i negativno mišljenje (Hooks, 2011, 596).

Pozitivno mišljenje revizora je najpoželjniji oblik mišljenja kako za klijenta revizije, korisnike finansijskih izveštaja tako i za samog revizora. Izražava se kada je na bazi analize prikupljenih dokaza revizor uveren da finansijski izveštaji istinito i objektivno po svim materijalno značajnim pitanjima prikazuju finansijski položaj društva, rezultate njegovog poslovanja, promene na kapitalu i tokove gotovine u godini za koju se obavlja revizija, u skladu su sa međunarodnim računovodstvenim standardima i zakonskim propisima. Kada revizor otkrije nepravilnosti koje po stepenu važnosti nisu bitne da bi ga opredelile da iznese mišljenje sa rezervom, ali nisu nevažne da se mogu zanemariti, iznosi pozitivno mišljenje uz skretanje pažnje na neka pitanja ili sitne propuste koje je u postupku revizije uočio. Mišljenje sa rezervom daje se za finansijske izveštaje koji su pravilno prikazani u skladu sa računovodstvenim standardima i zakonskim odredbama, osim za neke uočene nepravilnosti koje su materijalne po karakteru i bitne za donosioce odluka korisnike finansijskih izveštaja i revizorskog izveštaja, ali nemaju fundamentalan značaj koji bi naveo revizora da izrazi negativno mišljenje. Kada revizor poseduje više razloga za formiranje rezerve potrebno je da izvrši procenu kumulativnog efekta ukupnih nalaza koji su osnova kvalifikovanog mišljenja (Soltani, 2007, 349). Ukoliko je kumulativan efekat osnove neslaganja takav da utiče na istinitost finansijskih izveštaja, onda se neslaganja mogu okarakterisati kao fundamentalni propusti koji upućuju revizora na formulisanje negativnog mišljenja. 
Kada je priroda uočenog problema takva da $\mathrm{u}$ potpunosti osporava upotrebljivost finansijskih izveštaja za korisnike, neslaganje se smatra fundamentalnim, a finansijski izveštaji po mišljenju revizora nepouzdanim. U slučaju fundamentalnih nedostataka, izražavanje mišljenja sa rezervom od strane revizora ne bi predstavljalo dovoljno upozorenje korisnicima revizorskog izveštaja i finansijkih izveštaja osiguravajućeg društva na neistinitosti o finansijskom i zarađivačkom položaju društva. Ukoliko je, zahvaljujući uslovima obavljanja revizorskih postupaka, prisutna neizvesnost o istinitosti nekih bilansnih pozicija o kojima revizor nema dokaze, a neizvesnost ima fundamentalan uticaj na finansijske izveštaje u celini, izveštaji se smatraju nepouzdanim, a revizor zbog nedostatka dokaza uzdržava se od iznošenja mišljenja u revizorskom izveštaju. Uzdržavanje od iznošenja mišljenja pre se odnosi na uslove izvođenja revizije nego na karakter samih finansijskih izveštaja.

Izveštaj nezavisnog revizora kada je reč o klijentu revizije iz delatnosti osiguranja specifičan je u odnosu na druga privredna društva po tome što izveštaj nezavisnog revizora mora biti strukturiran u skladu sa zahtevima Odluke o sadržini izveštaja o obavljenoj reviziji finansijskih izveštaja društva za osiguranje donete od strane NBS. Prema navedenoj Odluci
(Službeni glasnik RS, 54/2005) izveštaj o reviziji sadrži mišljenje i izveštaj ovlašćenog revizora kao i analize i priloge. Analiza uz izveštaj o reviziji sadrži: opšte podatke o društvu, analizu sistema interne kontrole, analizu vođenja poslovnih knjiga, analizu bilansa stanja, bilansa uspeha, bilansa tokova gotovine, izveštaja o promenama na kapitalu, napomena uz finansijske izveštaje, pokazatelje poslovanja društva, analizu organizacione, kadrovske i tehničke osposobljenosti društva, analizu funkcionisanja interne revizije i analizu nalaza eksterne kontrole. Razlozi za propisivanje navedene analitičnosti i prikaza analiza leži u značaju koje osiguranje ima sa društvenog aspekta i potrebe održanja neophodne finansijske discipline. Nepoverenje $\mathrm{u}$ finansijsko izveštavanje ovih kompanija, odsustvo potrebne kredibilnosti informacija sadržanih u finansijskim izveštajima imalo bi domino efekat na narušavanje sigurnosti koje osiguranje treba da pruža kako u finansijskom tako i $\mathrm{u}$ realnom privrednom sektoru. Posmatrano globalno za sektor osiguranja u Republici Srbiji za poslovnu 2011. i 2012. godinu, revizori su izneli mišljenja u svojim izveštajima, kao što je dato u Tabeli 1.

Od 28 osiguravajućih društava u Republici Srbiji, za 2012. godinu pozitivno mišljenje su dobila 22 društva, 4 društva su dobila pozitivno mišljenje sa skretanjem

Tabela 1 Mišljenja revizora u revizorskim izveštajima za sektor osiguranja u 2011. i 2012, i pregled revizorskih kuća koje su angažovala osiguravajuća društva

\begin{tabular}{llllll}
\hline R.B. & Naziv društva & $\begin{array}{l}\text { Mišljenje revizora } \\
\text { u izveštaju 2011 }\end{array}$ & Naziv rev. Kuće & $\begin{array}{l}\text { Mišljenje revizora } \\
\text { u izveštaju 2012 }\end{array}$ & Naziv rev. Kuće \\
\hline 1 & METLIFE & Pozitivno & DELLOITE & Pozitivno & DELLOITE \\
2 & AMS & Pozitivno & VINČIĆ & Pozitivno & VINČIĆ \\
3 & AXA NEŽIVOTNO & Pozitivno & PWC & Pozitivno & PWC \\
4 & BASLER NEŽIVOTNO & Pozitivno & PWC & Pozitivno & PWC \\
5 & BASLER ŽIVOTNO & Pozitivno & PWC & Pozitivno & PWC \\
6 & CREDIT AGRICOLE LIFE (AXA) & Pozitivno & PWC & Pozitivno & PWC \\
7 & DDOR RE & Pozitivno & KPMG & Pozitivno & KPMG \\
8 & DELTA GENERALI & Pozitivno & PWC & Pozitivno & ERNST \& YOUNG \\
9 & DELTA GENERALI RE & Pozitivno & PWC & Pozitivno & ERNST \& YOUNG \\
10 & DUNAV OSIGURANJE & Pozitivno & KPMG & Sa rezervom & KPMG
\end{tabular}




\begin{tabular}{|c|c|c|c|c|c|}
\hline R.B. & Naziv društva & $\begin{array}{l}\text { Mišljenje revizora } \\
\text { u izveštaju } 2011\end{array}$ & Naziv rev. Kuće & $\begin{array}{l}\text { Mišljenje revizora } \\
\text { u izveštaju } 2012\end{array}$ & Naziv rev. Kuće \\
\hline 11 & DUNAV RE & Pozitivno & KPMG & Pozitivno & KPMG \\
\hline 12 & ENERGO PROJEKT GARANT & Pozitivno & MOORE STEPHENS & Pozitivno & MOORE STEPHENS \\
\hline 13 & GLOBOS & Pozitivno & MOORE STEPHENS & Pozitivno & MOORE STEPHENS \\
\hline 14 & GRAWE & Pozitivno & KPMG & Pozitivno & KPMG \\
\hline 15 & MERKUR & Pozitivno & KPMG & Pozitivno & KPMG \\
\hline 16 & SAVA ŽIVOTNO & Pozitivno & KPMG & Pozitivno & KPMG \\
\hline 17 & UNIKA NEŽIVOTNO & Pozitivno & KPMG & Pozitivno & KPMG \\
\hline 18 & UNIKA ŽIVOTNO & Pozitivno & KPMG & Pozitivno & KPMG \\
\hline 19 & WIENER & Pozitivno & KPMG & Pozitivno & KPMG \\
\hline 20 & WIENER RE & Pozitivno & KPMG & Pozitivno & KPMG \\
\hline 21 & DDOR NOVI SAD & $\begin{array}{l}\text { Pozitivno sa } \\
\text { skretanjem pažnje }\end{array}$ & ERNST \& YOUNG & Pozitivno & ERNST \& YOUNG \\
\hline 22 & MILENIJUM & $\begin{array}{l}\text { Pozitivno sa } \\
\text { skretanjem pažnje }\end{array}$ & $\begin{array}{l}\text { PRIVREDNI } \\
\text { SAVETNIK }\end{array}$ & $\begin{array}{l}\text { Pozitivno sa } \\
\text { skretanjem pažnje }\end{array}$ & $\begin{array}{l}\text { PRIVREDNI } \\
\text { SAVETNIK }\end{array}$ \\
\hline 23 & SOCIETE GENERALI & $\begin{array}{l}\text { Pozitivno sa } \\
\text { skretanjem pažnje }\end{array}$ & DELLOITE & Pozitivno & ERNST \& YOUNG \\
\hline 24 & TAKOVO & $\begin{array}{l}\text { Pozitivno sa } \\
\text { skretanjem pažnje }\end{array}$ & VINČIĆ & Sa rezervom & VINČIĆ \\
\hline 25 & SAVA & $\begin{array}{l}\text { Pozitivno sa } \\
\text { skretanjem pažnje }\end{array}$ & KPMG & $\begin{array}{l}\text { Pozitivno sa } \\
\text { skretanjem pažnje }\end{array}$ & KPMG \\
\hline 26 & TRIGLAV KOPAONIK & $\begin{array}{l}\text { Pozitivno sa } \\
\text { skretanjem pažnje }\end{array}$ & KPMG & $\begin{array}{l}\text { Pozitivno sa } \\
\text { skretanjem pažnje }\end{array}$ & ERNST \& YOUNG \\
\hline 27 & AS NEŽIVOTNO & Sa rezervom & VINČIĆ & $\begin{array}{l}\text { Pozitivno sa } \\
\text { skretanjem pažnje }\end{array}$ & VINČIĆ \\
\hline 28 & SOGAZ OSIGURANJE & & & Pozitivno & PWC \\
\hline
\end{tabular}

Izvor: Autor, na osnovu obelodanjenih finansijskih izveštaja pojedinačno za osiguravajuća društva, http://www.nbs.rs/internet/ cirilica/60/60_1/60_1_1.html, vreme pregleda februar 2014.

pažnje i 2 društva su dobila mišljenje sa rezervom. U odnosu na 2011. godinu, došlo je do rasta učešća pozitivnih revizorskih mišljenja za $4 \%$ (sa $74,07 \%$ na $78.57 \%$ ) što se vidi na Slici 2.

\section{ZAKLJUČAK}

Osnovni cilj revizije proističe iz uloge revizije da verifikuje finansijske izveštaje i zainteresovanim korisnicima autoritativno i kompetentno saopšti mišljenje o istinitosti i objektivnosti finansijskih izveštaja. Realna slika o finansijskoj stabilnosti osiguravajućeg društva značajna je za zaštitu interesa sadašnjih i potencijalnih osiguranika.

Precenjivanjem aktive radi prikrivanja neovlašćenog prisvajanja imovine društva direktno bi se ugrozili interesi osiguranika s obzirom na to da bi osiguravajuce društvo zapalo $\mathrm{u}$ teškoće ispunjenja preuzetih obaveza $u$ trenutku nastanka rizičnog događaja i potrebe nadoknade štete. Uloga institucije osiguranja - nadoknada štete osiguranicima i pružanje sigurnosti - bila bi osporena ako sama osiguravajuća društva ne bi bila sposobna da odgovore na potrebu servisiranja nastalih obaveza prema osiguranicima. Usled ove 


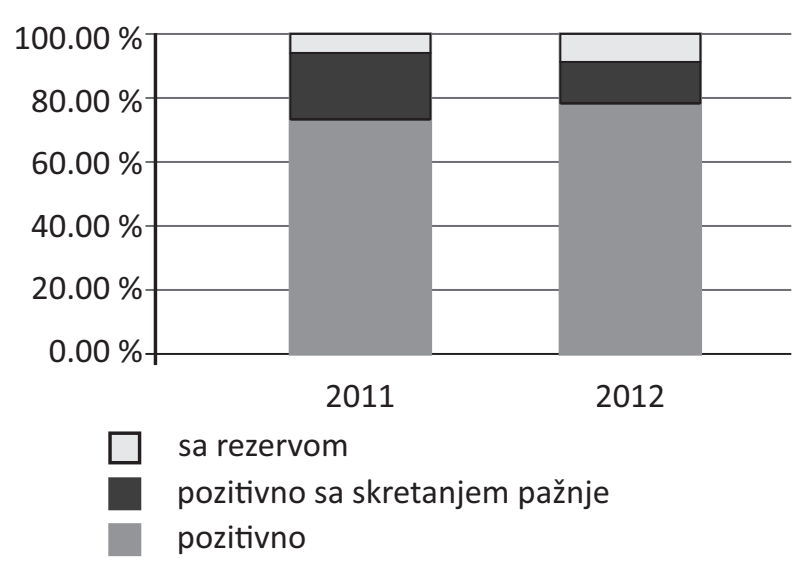

Slika 2 Učešće pojedinih mišljenja revizora za osiguravajuća društava u 2011. i 2012.

Izvor: Autor

društvene važnosti osiguranja, naglašena je potreba realnog finansijskog izveštavanja osiguravajućih društava i potreba sprovođenja revizije njihovih izveštaja sa posebnim profesionalnim skepticizmom kako bi se korisnici revidiranih finansijskih izveštaja mogli pouzdati $\mathrm{u}$ informacije koje su $\mathrm{u}$ njima obelodanjene. U suprotnom, osiguranje ne bi pružalo sigurnost u društvenoj zajednici već bi, naprotiv, bilo izvor nesigurnosti koji ima dalekosežne negativne efekte usled domino efekta $u$ finansijskom sistemu neke zemlje.

Ključna hipoteza od koje se u radu pošlo je potvrđena kroz primenu odgovarajućih tehnika prikupljanja dokaza u zavisnosti koji pojedinačni revizorski ciljevi se žele potvrditi u ispitivanju pojedine bilansne pozicije u finansijskim izveštajima osiguravajućeg društva. Takođe, u radu je potvrđeno da pojedinačni revizorski ciljevi nemaju istu važnost za svaku bilansnu poziciju, neki revizorski ciljevi poput postojanja i vlasništva akcentovani su u proveri od strane revizora kada je reč o aktivnim bilansnim pozicijama, dok su revizorski ciljevi poput vrednovanja i potpunosti naglašeni kada se ispituju pasivne bilansne pozicije pogotovo kod ispitivanja rezervisanih šteta i dugoročnih rezervisanja.
Osnovni doprinos ovog rada ogleda se $\mathrm{u}$ analizi adekvatnosti primene postojećih metoda i postupaka ispitivanja korišćenih od strane revizora $\mathrm{u}$ procesu prikupljanja dokaza o finansijskim izveštajima osiguravajućih društava i kritičkom osvrtu na njihovu primerenost specifičnostima poslovanja osiguravajućih društava. Ova analiza omogućava definisanje predloga za unapređenje i modifikaciju pojedinih tehnika u skladu sa diferenciranjem prioritetnosti pojedinih revizorskih ciljeva.

Cilj postojanje je prioritetan $\mathrm{u}$ odnosu na druge revizorske ciljeve kada se ispituju novčana sredstva osiguravajućeg društva, što uslovljava unapređenje tehnike konfirmacije $u$ smislu njenog isključivog korišćenja $\mathrm{u}$ obliku pozitivne konfirmacije i njena upotreba za ispitivanje svih depozita koji sačinjavaju tehničke rezerve društva. Neizvesnost nastanka rizika nameće potrebu držanja veće količine gotovine u osiguravajućem društvu, što povećava mogućnost nastanka pronevera iste. Revizorski cilj kompletnost smatra se primarnim ciljem za ispitivanje pozicija bilansa uspeha $\mathrm{i}$ ispitivanje obaveza društva $\mathrm{u}$ bilansu stanja. Potreba detaljnijeg ispitivanja cilja kompletnosti nameće neophodnost dosledne primene pristupa traganja u prikupljanju dokaza. Ovaj metod prikupljanja dokaza neophodno je prilagoditi kada je reč o ispitivanju u osiguravajućem društvu u smislu njegove ekstenzivnije primene na veći broj ispitanih jedinica isključivom upotrebom slučajnog uzorka iz celokupne populacije jednorodnog tipa dokumenta.

Osnovno ograničenje $u$ radu odnosi se na delimiču analizu primene tehnika prikupljanja dokaza samo na najvažnije i specifične bilansne pozicije u osiguravajućim društvima ne produbljujući ovu tematiku na sve bilansne pozicije koje postoje u društvu i u preduzećima koja se bave drugim delatnostima, kako bi se izbegla preterana ekstenzivonost rada. Takođe, prikazana je primena najvažnijih tehnika prikupljanja dokaza koje se prilagođavaju $u$ prikupljanju dokaza u osiguranju, ali ne i sve tehnike za sve revizorske ciljeve.

S obzirom na to da se osiguranje zasniva na postojanju rizika, buduća istraživanja treba usmeriti na ispitivanje preuzetih rizika i rizičnosti poslovne aktivnosti osiguravajućeg društva primenom relevantnog 
postupka provere od strane revizora, kako bi se na osnovu analize omogućilo unapređenje revizorskih procedura prikupljanja dokaza u postupku revizije finansijskih izveštaja osiguravajućih društava. Unapređenje revizorskih procedura kroz adaptaciju primene poznatih tehnika prikupljanja dokaza povećava kredibilitet finansijskih izveštaja, a donošenje poslovnih odluka, zasnovano na revidiranim informacijama, čini sigurnijim.

\section{ZAHVALNICA}

Ovaj rad je deo Projekta osnovnih istraživanja (br. 42013), koji finansira Ministarstvo prosvete, nauke i tehnološkog razvoja Republike Srbije.

\section{REFERENCE}

Boynton, W., \& Johnson, R. (2006). Modern Auditing Assurance Services and the Integrity of Financial Reporting. New York, USA: Jonh \& Sons.

Cosserat, G., \& Rodda, N. (2009). Modern auditing. London, UK: Wiley \& Sons.

Eilifsen, A., Messier, W., Glover, S., \& Prawitt, D. (2014). Auditing $\mathcal{E}$ Assurance Services. London, UK: McGraw-Hill Education.

Finansijski izveštaji osiguravajućih društava., (2011. i 2012.). Dostupno na http://www.nbs.rs/internet/ cirilica/60/60_1/60_1_1.html vreme pregleda februar 2014.

Hooks, K. (2011). Auditing and Assurance Services: Understanding the Integrated Audit. Danver, USA: John Wiley \& Sons.

Jovković, B. (2010). Primena postupaka uzorkovanja revizora za svrhu testiranja kontrola preduzeća klijenta. Ekonomski horizonti, 12(2), 133-155.

Jovković, B. (2011). Testiranje realnosti ciklusa transakcija i salda računa zaliha i stalne imovine. Ekonomski horizonti, 13(2), 87-105.

Malinić, S. (1999). Organizacija računovodstva. Kragujevac, Republika Srbija: Ekonomski fakultet.

Međunarodni računovodstveni standardi. MRS 21 „Efekti promena deviznih kurseva“. „Službeni glasnik RS“ 16/2008.

Međunarodni standardi revizije (2010). Beograd, Republika Srbija: SRRS.

Narodna banka Srbije http://www.nbs.rs/internet/ cirilica/60/60_1/60_1_1.html, vreme pregleda februar 2014.

Odluka o sadržini izveštaja o obavljenoj reviziji finansijskih izveštaja društva za osiguranje, „Službeni glasnik RS“ br. 21/2005., 24/2005., 54/2005.

Pjanić, Z., Stojanović, I., i Jakšić, M. (1994). Ekonomska i poslovna enciklopedija. Beograd, Republika Srbija: Savremena administracija.

Rittenberg, L., Schwieger, B., \& Johnstone, K. (2008). Auditing: A Business Risk Approach. Mason, USA: Thomson SouthWestern.

Soltani, B. (2007). Auditing - An International Approach. Harlow, England: Prentice Hall.

Whittington, R., \& Pany, K. (2014). Principles of Auditing and Other Assurance Services. New York, USA: McGraw-Hill.

Zakon o obligacionim odnosima. „Sl. list SFRJ”, br. 29/78, 39/85, 45/89 - odluka USJ i 57/89, „Sl. list SRJ”, br. 31/93 i „Sl. list SCG", br. 1/2003 - Ustavna povelja.

Zakon o računovodstvu i reviziji. „Službeni glasnik RS“ br. 46/2006. i 111/2009.

Zakon o reviziji. „Službeni glasnik RS“ br. 62/2013. Dostupno na http://www.parlament.rs/upload/archive/files/lat/pdf/ zakoni/2013/2270-13Lat.pdf.

Zakon o računovodstvu. „Službeni glasnik RS“ br. 62/2013. Dostupno na http://www.parlament.rs/upload/archive/files/ lat/pdf/zakoni/2013/2276-13Lat.pdf. 
Biljana Jovković je docent na nastavnim predmetima Računovodstvo finansijskih organizacija i Revizija finansijskih izveštaja, na Ekonomskom fakultetu Univerziteta u Kragujevcu, gde je i doktorirala. Ključne oblasti njenog interesovanja su računovodstvo u osiguravajućim kompanijama i bankama, revizija finansijskih izveštaja, interna kontrola i interna revizija.

\title{
APPLICATION OF EVIDENCE-COLLECTION TECHNIQUES IN EXAMINING THE BASIC AUDIT OBJECTIVES IN INSURANCE COMPANIES
}

\author{
Biljana Jovkovic \\ Faculty of Economics, University of Kragujevac, Kragujevac, Serbia
}

The independent auditor expresses his or her opinion on financial reports, whose primary role is to reduce the asymmetry of information between insurance companies' management and the existing and potential investors. Through reducing the information risk of the presented financial reports, audit provides the safer making of investment decisions of the users of these reports. In order for this basic function of audit to realize, it is necessary that auditors should collect sufficient pieces of evidence by applying adequate and relevant examination techniques. The goal of this paper is to point at the specific position of audit when an insurance company is a client, and in this regard, at a need for the differentiation of the priorities of individual audit objectives as well as the necessity of the customization of the implemented evidencecollection techniques implemented in an audit engagement with an insurance company simultaneously respectfully referring to the prescribed ordinary procedures imposed by the professional regulation. In the paper, an attempt has been made to comprehensively analyze the effectiveness of individual evidencecollection techniques for the purpose of proving the achievement of each individual objective of the audit as well as their different applicability in the examination of certain balance-sheet positions in financial reports of insurance companies.

Keywords: evidence-collection techniques, audit objectives, financial reports of insurance companies

JEL Classification: G22, M42 